\title{
EFEK PENAMBAHAN GELATIN TERHADAP EDEMA OLEH LARUTAN Smilax Sp
}

\author{
Komaria Ramatuan', Aung Sumbono,3, Jaharudin ${ }^{1}$ \\ ${ }^{1}$ Program Studi Pendidikan Biologi FKIP UNIMUDA Sorong \\ ${ }^{2}$ LP3M UNIMUDA Sorong \\ ${ }^{3}$ Program Studi Farmasi FST UNIMUDA Sorong \\ Khomaryha@gmail.com
}

\begin{abstract}
ABSTRAK
Penelitian ini untuk mengetahui efek penambahan gelatin terhadap edema oleh larutan Smilax Sp. Metode yang dipakai adalah eksperimen menggunakan instrumen obsevasi, dokumentasi, mikroskop dan alat ukur. Tempat penelitian Laboratorium Terpadu UNIMUDA Soron.. Sampel yang digunakan ialah daun Smilax Sp segar sebanyak 20 gr, Gelatin 2,5 gr dan Fgg berumur 1 bulan 10 ekor. Teknik analisis data yang digunakan ialah perbandingan dan persentase. Hasil penelitian dapat disimpulkan bahwa pengaruh dari penambahan gelatin mengalami efek edema baik dari sisi waktu proses terjadinya edema, maupun dari besarnya edema dimana penambahan gelatin mengakibatkan memperlambat proses edema dan memperkecil besar edema. Beberapa sampel menunjukkan bahwa lamanya waktu dapat berpangaruh pada edema, dikarenakan waktu maksimal pencapaian suatu zat bervariasi. Edema pada penelitian ini memiliki persentase massa tertinggi pada jam ke 20 (S10) sebesar 27,98\%, kelilingnya pada jam ke 12 (S6) sebesar 9,89\%, tebalnya pada jam ke 16 (S8) 2\% dan lebarnya pada jam ke 20 (10) $125,79 \%$.
\end{abstract}

Kata Kunci : Edema, Gelatin, Smilax Sp.

ABSTRACT
This study was to see the effect of adding gelatin to edema by a solution of Smilax Sp. The method used is an experiment using observation instruments, documentation, microscopes and measuring instruments. The research site is the Integrated Laboratory of UNIMUDA Soron. The samples used were 20 gr fresh Smilax Sp leaves, $2.5 \mathrm{~g}$ Gelatin and 101 month old Fgg. The data analysis technique used was comparison and proportion. The results can be ignored that the effect of adding gelatin has an edema effect both in terms of the timing of the edema process, as well as the size of the edema where the addition of gelatin causes delays in the edema process and reduces large edema. Some samples show that time can have an effect on edema, because the maximal time of the variable varies. Edema in this study had the highest mass proportion at the 20th hour (S10) of 27.98\%, the circumference at the 12th hour (S6) 9.89\%, the thickness at the 16th hour (S8) 2\% and the width at the 20th hour. (10) $125.79 \%$.

Keywords: Edema, Gelatin, Smilax Sp.

\section{Pendahuluan}

Edema adalah pembengkakan yang terjadi ketika adanya kelebihan cairan interstitial dalam jaringan tubuh (1). Edema umumnya dapat timbul melalui dua proses yang berbeda (2). Edema dapat disebabkan karena adanya tekanan di dalam pembuluh darah, penumpukan cairan setelah pengangkatan kelenjar getah bening, peradangan, retensi air, tekanan hidrostatik, tekanan onkotik jaringan (interstitial) (3). Selain beberapa penyebab edema di atas edema juga dapat disebabkan karena adanya larutan.

Larutan adalah suatu campuran homogen yang terdiri dari dua atau lebih zat dalam komposisi yang bervariasi(4). Di dalam larutan terdapat zat- zat yaitu zat yang jumlahnya lebih sedikit di dalam larutan disebut (zat) terlarut, sedangkan zat yang jumlahnya lebih banyak dari pada zat-zat lain dalam larutan disebut pelarut(5). Salah satu zat yang dapat dijadikan sebagai zat penambah larutan adalah gelatin.

Gelatin adalah protein makromolekul dan biodegradable yang terjadi secara alami dan dihasilkan oleh hidrolisis parsial terkontrol yang disintesis dari kulit kolagen, jaringan ikat putih dan tulang-tulang hewan yang tersusun dari residu asam amino pada proporsi dan kombinasi berbeda (6). Gelatin juga merupakan salah satu bahan yang paling

banyak digunakan dalam industri makanan (7). Gelatin umumnya digunakan sebagai agen pembentuk gel dalam pembuatan makanan(8). Karena gelatin mengandung asam amino (prolin dan hidroksiproli) (9). Dalam industri farmasi, gelatin dapat digunakan untuk memproduksi obat- obatan (kapsul lunak dan keras), pembalut luka dan bantalan adsorben(10). Selain dari obat-obatan tersebut adapula obat tradisional yang dapat menyebabkan edema yakni Smilax.

Smilax (Smilacaceae) merupakan satu marga tumbuhan yang tersebar pada daerah tropis maupun subtropis, terdiri dari lebih kurang 300 jenis(11). Smilax Sp sudah dilakukan pemanfaatannya untuk bidang kesehatan masyarakat terutama untuk obat tradisional. Salah satu pengobatan tradisional Papua menggunakan tanaman Smilax $S p$.

Masyarakat asli Papua menggunakan tanaman Smilax Sp sebagai obat pembesar alat kelamin, namun pada jangka waktu pemakaian yang terlalu lama dapat menyebabkan pecahnya pembuluh darah. Berdasarkan efek negatif yang ditimbulkan dari penggunaan tanaman Smilax $S p$ maka perlu dilakukan suatu 
penelitian tentang penggunaan tanaman Smilax Spdengan tambahan gelatin.

\section{METODE PENELITIAN}

Pendekatan yang dipakai dalam penelitian ini adalah penelitian eksperimen. (12). Penelitian pada tanggal 28 April 2020, yang bertempat dilaboratorium MIPA Universitas Pendidikan Muhammadiyah (UNIMUDA) Sorong.

Langkah-langkah pembuatan ekstrak daun Smilax $S p$ yang dibalutkan pada sampel yakni memisahkan daun dari batangnya atau tulang daun menggunakan pisau, kemudian ditimbang menggunakan timbangan analitik. Cuci daun menggunakan air bersih hingga daun tersebut bersih, setelah itu tiriskan. Haluskan daun menggunakan mortar dan tambahkan air $10 \mathrm{ml}$. Setelah halus, pindahkan daun tersebut dibagian tengah saringan plastik lalu disaring untuk mengambil larutannya. Setelah itu, larutan yang sudah didapatkan dicampur dengan 2,5 gr gelatin agar larutan menjadi salep. Salep tersebut dioleskan pada Femur Gallus gallus, kemudian bungkus Femur Gallus gallus menggunakan kain kasa dan ikat menggunakan kain kasa. Diamkan selama 2 jam, 4 jam, 6 jam, 8 jam, 10 jam, 12 jam, 14 jam, 16 jam, 18 jam dan 20 jam. (13).

Kontrol tidak diberi perlakuan apapun (normal)

Populasi dalam penelitian ini yakni tanaman obat dan hewan yang diperoleh dari Kabupaten Sorong. Sampel adalah bagian dari populasi yang menjadi objek penelitian (sampel sendiri secara harfiah berarti contoh)(14). Sampel dalam penelitian ini yakni tanaman Smilax $S p$ dan Gallus gallus yang diperoleh dari Kabupaten Sorong. Tanaman Smilax Sp yang dipakai adalah daun yang baru dipetik, Gallus gallus yang dipakai sebagai sampel adalah Gallus gallus domesticus yang berumur 1 bulan, dalam kondisi sehat, dan pakan terjamin.

Bahan yang digunakan dalam penelitian ini yaitu : Daun tumbuhan Smilax Sp, Gelatin, Air bersih dan Gallus gallus domesticus Alat yang digunakan dalam penelitian ini yaitu : Timbangan (analitik), nampan, gunting, gunting bedah, pisau, mortar dan pastle, penggaris, pengaduk, spatula, tabel warna, mikroskop, kamera, ember, kain kasa dan perban.

Teknik analisis data dalam penelitian ini yakni dilakukan perbandingan bentuk, ukuran, berat, dan warna antara Femur Gallus-gallus domesticus sampel dengan Femur Gallus-gallus domesticus kontrol dalam bentuk persentase.

\section{HASIL DAN PEMBAHASAN}

Data massa antara Femur Gallus gallus domesticus (Fgg) sampel eksperimen (FE) dan Fgg sampel kontrol (FK) ditampilkan pada gambar 3-1

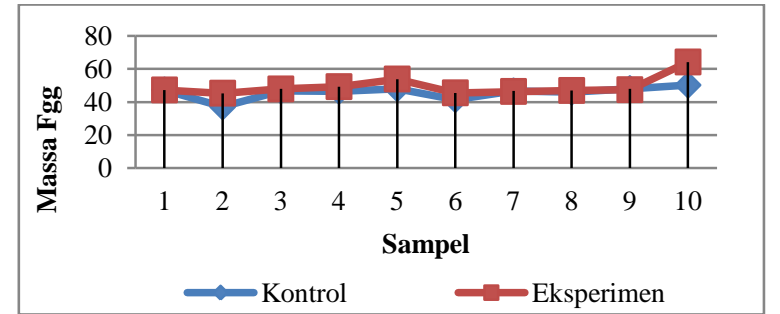

Gambar 3-1 Grafik Data hasil Massa Fgg

Data pada gambar 3-1 menunjukan bahwa massa terendah dari FK terdapat pada sampel 2 (S2) yakni 36,99 gr dan massa tertingginya terdapat pada S10 yakni 50,17 gr dengan rata-ratanya yakni 457,77 gr. Sedangkan massa terendah dari FE terdapat pada S2 yakni 45,28 gr dan massa tertingginya terdapat pada S10 yakni 64,21 gr dengan rata-ratanya yakni 493,88 gr.

Data keliling Superius antara Fgg sampel FE dan Fgg sampel FK di tampilkan pada gambar 3-2

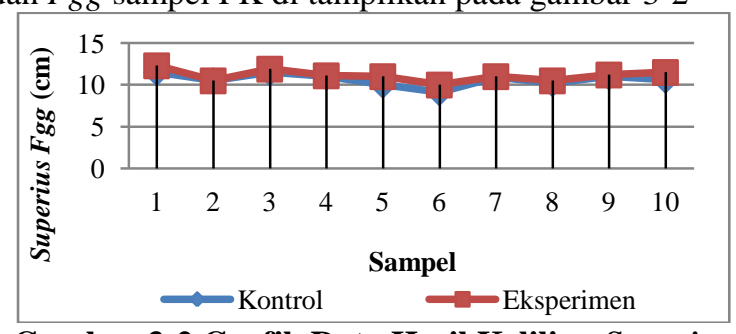

Gambar 3-2 Grafik Data Hasil Keliling Superius Fgg

Data pada gambar 3-2 menunjukan bahwa keliling terendah dari Superius FK terdapat pada S6 yakni $9,1 \mathrm{~cm}$ dan keliling tertingginya terdapat pada S1 dan S6 yakni $11.5 \mathrm{~cm}$ dengan rata-ratanya yakni $106,3 \mathrm{~cm}$. Sedangkan keliling terendah dari FE terdapat pada $\mathrm{S} 6$ yakni $10 \mathrm{~cm}$ dan keliling tertingginya terdapat pada S1 yakni $12.3 \mathrm{~cm}$ dengan rata-ratanya yakni $111 \mathrm{~cm}$.

Data keliling Medio antara Fgg sampel FE dan Fgg sampel FK di tampilkan pada gambar 3-3

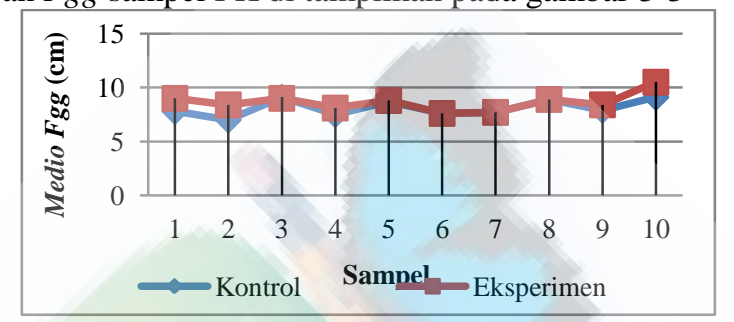

Gambar 3-3 Grafik Data Hasil Keliling Medio Fgg

Data pada gambar 3-3 menunjukan bahwa keliling terendah dari Medio FK terdapat pada S2 yakni $7 \mathrm{~cm}$ dan keliling tertingginya terdapat pada S3 dan S10 yakni 9,1 cm dengan rata-ratanya yakni 81,3 $\mathrm{cm}$. Sedangkan keliling terendah dari Medio FE terdapat pada S6 yakni 7,6 cm dan keliling tertingginya terdapat pada $\mathrm{S} 10$ yakni $10,5 \mathrm{~cm}$ dengan rata-ratanya yakni $86,4 \mathrm{~cm}$.

Data keliling Inferiora antara Fgg sampel FE dan Fgg sampel FK di tampilkan pada gambar 3-4 


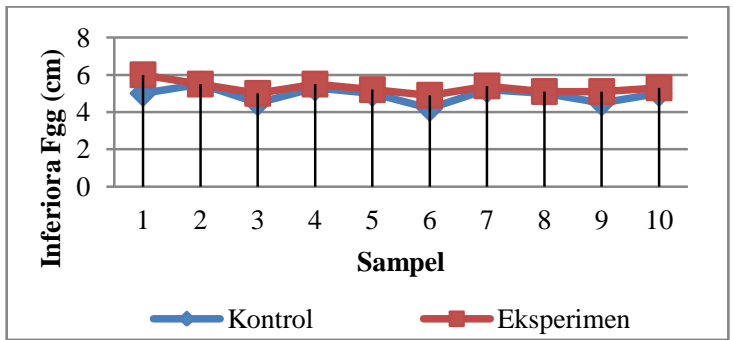

Gambar 3-4 Grafik Data Hasil Keliling Inferiora Fgg

Data pada gambar 3-4 menunjukan bahwa keliling terendah dari Inferiora FK terdapat pada S6 yakni 4,2 $\mathrm{cm}$ dan keliling tertingginya terdapat pada $\mathrm{S} 2$ yakni $5,5 \mathrm{~cm}$ dengan rata-ratanya yakni 49,2 cm. Sedangkan keliling terendah dari FE terdapat pada S6 yakni 4,9 $\mathrm{cm}$ serta keliling tertingginya terdapat pada $S 1$ yakni 6 $\mathrm{cm}$ dengan rata-ratanya yakni $53 \mathrm{~cm}$.

Data tebal Faciem Superius antara Fgg sampel FE dan Fgg sampel FK di tampilkan pada gambar 3-5

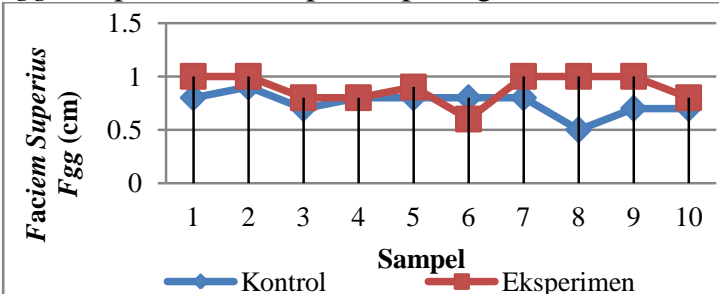

\section{Gambar 0-5 Grafik Data Hasil Tebal Faciem} Superius Fgg

Data pada gambar 3-5 menunjukan bahwa tebal terendah dari Faciem Superius FK terdapat pada S7 yakni $0,5 \mathrm{~cm}$ serta tebal tertingginya terdapat pada $\mathrm{S} 2$ yakni $0.9 \mathrm{~cm}$ dengan rata-ratanya yakni $7,5 \mathrm{~cm}$. Sedangkan tebal terendah dari FE terdapat pada S6 yakni $0,6 \mathrm{~cm}$ serta tebal tertingginya terdapat pada $S 1$, $\mathrm{S} 2, \mathrm{~S} 7, \mathrm{~S} 8$ dan $\mathrm{S} 9$ yakni $1 \mathrm{~cm}$ dengan rata-ratanya yakni $8,9 \mathrm{~cm}$.

Data tebal Faciem Medio antara Fgg sampel FE dan Fgg sampel FK di tampilkan pada gambar 3-6

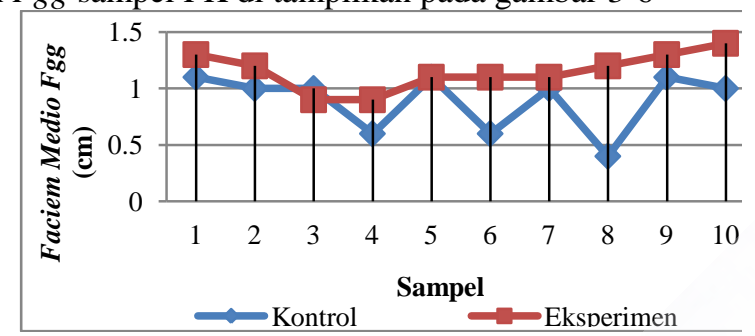

\section{Gambar 3-6 Grafik Data Hasil Tebal Faciem} Medio Fgg

Data pada gambar 3-6 menunjukan bahwa tebal terendah dari Faciem Medio FK terdapat pada S7 yakni $0,4 \mathrm{~cm}$ dan tebal tertingginya terdapat pada $\mathrm{S} 1$, S5 dan S9 yakni 1,1 cm dengan rata-ratanya yakni 8,9 $\mathrm{cm}$. Sedangkan tebal terendah dari FE terdapat pada $\mathrm{S} 3$ dan S4 yakni $0,9 \mathrm{~cm}$ dan tebal tertingginya terdapat pada $\mathrm{S} 10$ yakni $1,4 \mathrm{~cm}$ dengan rata-ratanya yakni 11,5 $\mathrm{cm}$.

Data tebal Faciem Medio antara Fgg sampel FE dan Fgg sampel FK di tampilkan pada gambar 3-7

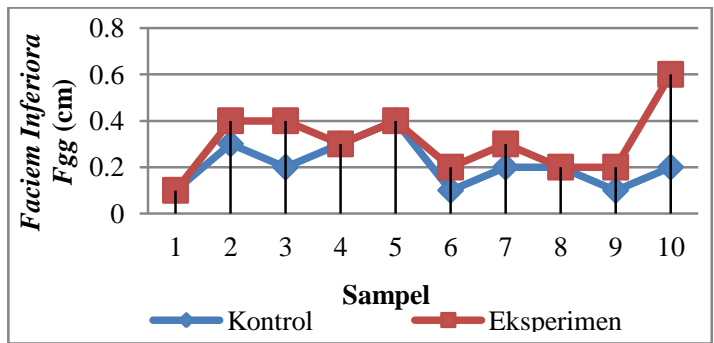

Gambar 3-7 Grafik Data Hasil Tebal Faciem Inferiora Fgg

Data pada gambar 3-7 menunjukan bahwa tebal terendah dari Faciem Inferiora FK terdapat pada S1, S6 dan $\mathrm{S} 9$ yakni $0,1 \mathrm{~cm}$ dan tebal tertingginya terdapat pada S5 yakni $0,4 \mathrm{~cm}$ dengan rata-ratanya yakni 2,1 $\mathrm{cm}$. Sedangkan tebal terendah dari FE terdapat pada $\mathrm{S} 1$ yakni $0,1 \mathrm{~cm}$ dan tebal tertingginya terdapat pada $\mathrm{S} 10$ yakni $0,6 \mathrm{~cm}$ dengan rata-ratanya yakni $3,1 \mathrm{~cm}$.

Data tebal Tergo Superius antara Fgg sampel FE dan Fgg sampel FK di tampilkan pada gambar 3-8

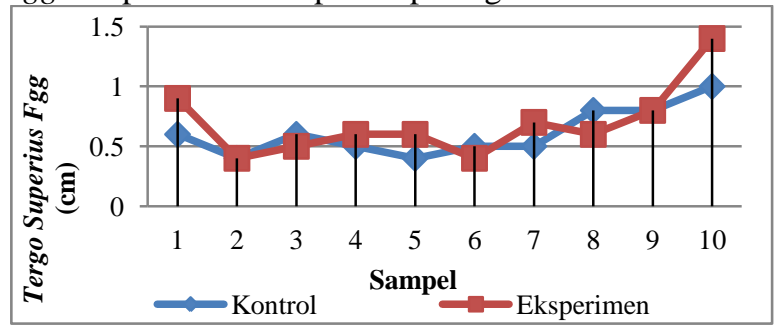

Gambar 3-8 Grafik Data Hasil Tebal Tergo Superius Fgg

Data pada gambar 3-8 menunjukan bahwa tebal terendah dari Tergo Superius FK terdapat pada S2 dan $\mathrm{S} 5$ yakni $0,4 \mathrm{~cm}$ dan tebal tertingginya terdapat pada $\mathrm{S} 10$ yakni $1 \mathrm{~cm}$ dengan rata-ratanya yakni $6,1 \mathrm{~cm}$. Sedangkan tebal terendah dari FE terdapat pada S2 dan S6 yakni $0,4 \mathrm{~cm}$ dan tebal tertingginya terdapat pada $\mathrm{S} 10$ yakni $1,4 \mathrm{~cm}$ dengan rata-ratanya yakni 6,9 $\mathrm{cm}$.

Data tebal Tergo Medio antara Fgg sampel FE dan Fgg sampel FK di tampilkan pada gambar 3-9

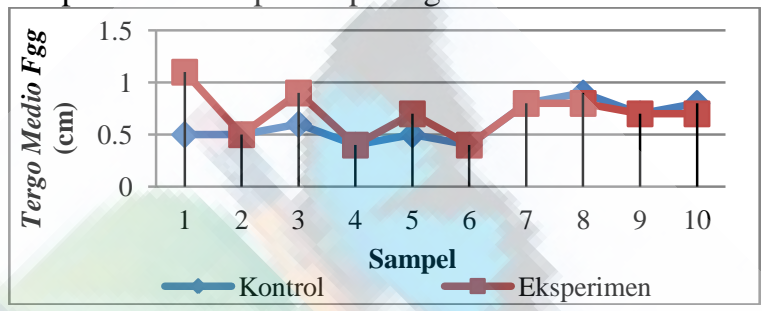

Gambar 3-9 Grafik Data Hasil Tebal Tergo Medio Fgg

Data pada gambar 3-9 menunjukan bahwa tebal terendah dari Tergo Medio FK terdapat pada S4 dan S6 yakni $0,4 \mathrm{~cm}$ dan tebal tertingginya terdapat pada S8 yakni $0,9 \mathrm{~cm}$ dengan rata-ratanya yakni $6,1 \mathrm{~cm}$. Sedangkan tebal terendah dari FE terdapat pada S4 dan S6 yakni $04 \mathrm{~cm}$ dan tebal tertingginya terdapat pada $\mathrm{S} 1$ yakni $1,1 \mathrm{~cm}$ dengan rata-ratanya yakni 7,3 $\mathrm{cm}$.

Data tebal Tergo Inferiora antara Fgg sampel FE dan Fgg sampel FK di tampilkan pada gambar 3-10 


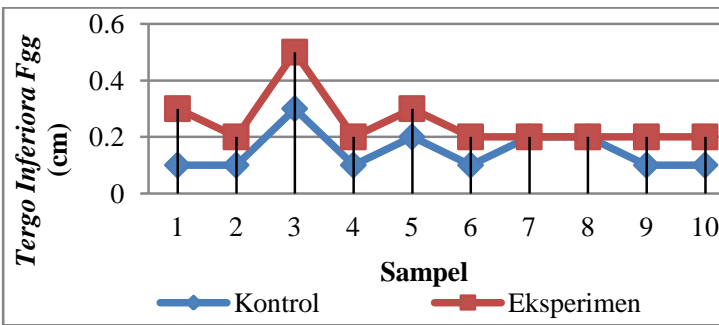

Gambar 3-10 Grafik Data Hasil Tebal Tergo Inferiora Fgg

Data pada gambar 3-10 menunjukan bahwa tebal terendah dari Tergo Inferiora FK terdapat pada S1, S2, S4, S6, S9, dan S10 yakni $0,1 \mathrm{~cm}$ dan tebal tertingginya terdapat pada $S 3$, yakni $0.3 \mathrm{~cm}$ dengan rata-ratanya yakni $1,5 \mathrm{~cm}$. Sedangkan tebal terendah dari FE terdapat pada S2, S4, S6, S7, S8, S9, dan S10 yakni $0,2 \mathrm{~cm}$ dan tebal tertingginya terdapat pada $\mathrm{S} 3$ yakni $0,5 \mathrm{~cm}$ dengan rata-ratanya yakni $2,5 \mathrm{~cm}$.

Data tebal Sinistram Superius antara Fgg sampel

FE dan Fgg sampel FK di tampilkan pada gambar 3-11

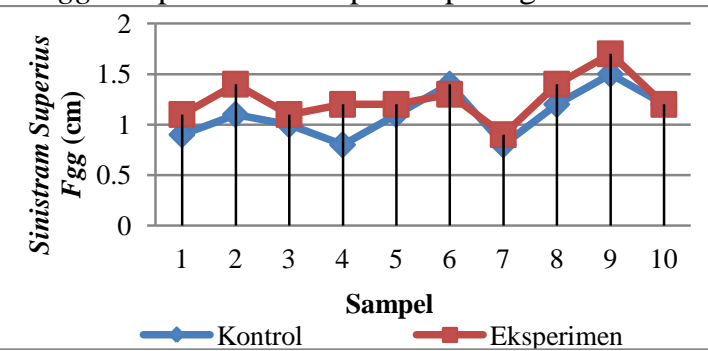

Gambar 3-11 Grafik Data Hasil Tebal Sinistram Superius Fgg

Data pada gambar 3-11 menunjukan bahwa tebal terendah dari Sinistram Superius FK terdapat pada S4 dan $\mathrm{S} 7$ yakni $0,8 \mathrm{~cm}$ dan tebal tertingginya terdapat pada $\mathrm{S} 9$, yakni $1,5 \mathrm{~cm}$ dengan rata-ratanya yakni 10,9 $\mathrm{cm}$. Sedangkan tebal terendah dari FE terdapat pada S7 yakni $0,9 \mathrm{~cm}$ dan tebal tertingginya terdapat pada S9 yakni $1,7 \mathrm{~cm}$ dengan rata-ratanya yakni $25,2 \mathrm{~cm}$.

Data tebal Sinistram Medio antara Fgg sampel FE dan Fgg sampel FK di tampilkan pada gambar 3-12

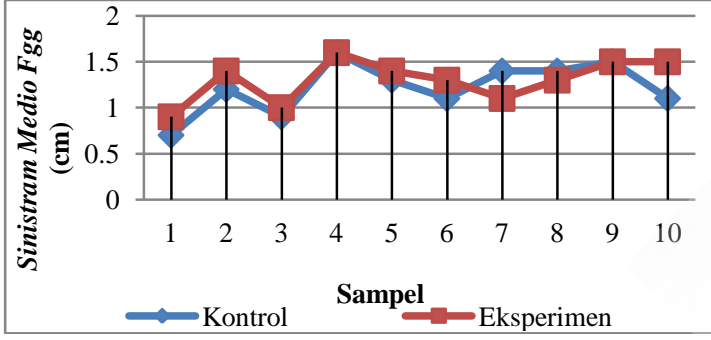

Gambar 3-12 Grafik Data Hasil Tebal Sinistram Medio Fgg

Data pada gambar 3-12 menunjukan bahwa tebal terendah dari Sinistram Medio FK terdapat pada S1 yakni $0,7 \mathrm{~cm}$ dan tebal tertingginya terdapat pada $\mathrm{S} 4$ yakni $1,6 \mathrm{~cm}$ dengan rata-ratanya yakni $12,2 \mathrm{~cm}$. Sedangkan tebal terendah dari FE terdapat pada S1 yakni $0,9 \mathrm{~cm}$ dan tebal tertingginya terdapat pada $\mathrm{S} 4$ yakni $1,6 \mathrm{~cm}$ dengan rata-ratanya yakni 13,5 .

Data tebal Sinistram Inferiora antara Fgg sampel FE dan Fgg sampel FK di tampilkan pada gambar 3-13

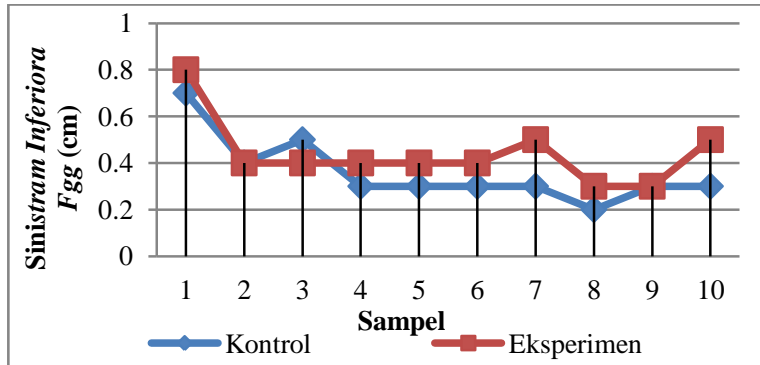

Gambar 3-13 Grafik Data Hasil Tebal Sinistram Inferiora Fgg

Data pada gambar 3-13 menunjukan bahwa tebal terendah dari Sinistram Inferiora FK terdapat pada S8 yakni $0,2 \mathrm{~cm}$ dan tebal tertingginya terdapat pada $\mathrm{S} 1$ yakni $0.7 \mathrm{~cm}$ dengan rata-ratanya yakni $3,6 \mathrm{~cm}$. Sedangkan tebal terendah dari FE terdapat pada S8 dan S9 yakni $0,3 \mathrm{~cm}$ dan tebal tertingginya terdapat pada $\mathrm{S} 1$ yakni $0,8 \mathrm{~cm}$ dengan rata-ratanya yakni 4,5 $\mathrm{cm}$.

Data tebal Dektrum Superius antara Fgg sampel FE dan Fgg sampel FK di tampilkan pada gambar 3-14

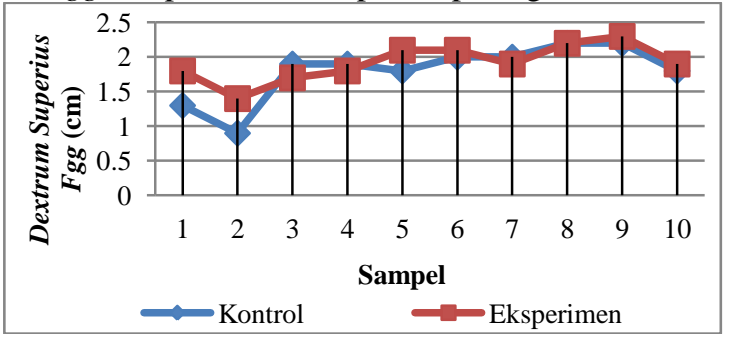

Gambar 3-14 Grafik Data Hasil Tebal Dextrum Superius Fgg

Data pada gambar 3-14 menunjukan bahwa tebal terendah dari Dextrum Superius FK terdapat pada S2 yakni $0,9 \mathrm{~cm}$ dan tebal tertingginya terdapat pada $\mathrm{S} 8$ dan S9 yakni 2,2 cm dengan rata-ratanya yakni $18 \mathrm{~cm}$. Sedangkan tebal terendah dari FE terdapat pada S2 yakni $1,4 \mathrm{~cm}$ dan tebal tertingginya terdapat pada $\mathrm{S} 9$ yakni 2,3 cm dengan rata-ratanya yakni $19.8 \mathrm{~cm}$.

Data tebal Dektrum Medio antara Fgg sampel FE dan Fgg sampel FK di tampilkan pada gambar 3-15

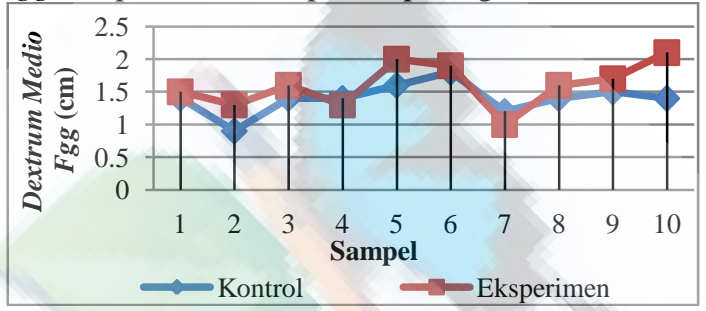

Gambar 3-15 Grafik Data Hasil Tebal Dextrum Medio Fgg

Data pada gambar 3-15 menunjukan bahwa tebal terendah dari Dextrum Medio FK terdapat pada S2 yakni $0,9 \mathrm{~cm}$ dan tebal tertingginya terdapat pada $\mathrm{S} 6$ yakni 1,8 cm dengan rata-ratanya yakni $13,8 \mathrm{~cm}$. Sedangkan tebal terendah dari FE terdapat pada S7 yakni $1 \mathrm{~cm}$ dan tebal tertingginya terdapat pada $\mathrm{S} 10$ yakni 2,1 cm dengan rata-ratanya yakni $16,2 \mathrm{~cm}$

Data tebal Dektrum Inferiora antara Fgg sampel FE dan Fgg sampel FK di tampilkan pada gambar 3-16 


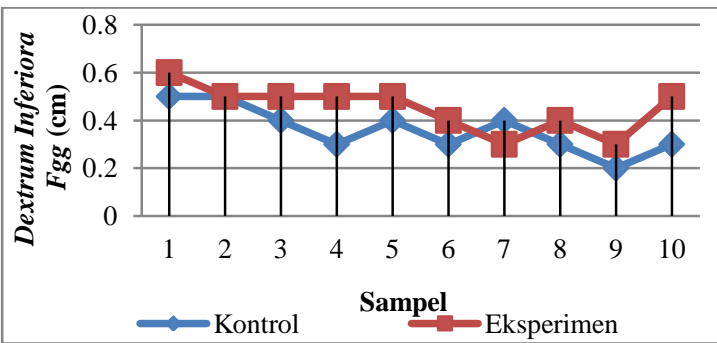

Gambar 3-16 Grafik Data Hasil Tebal Dektrum Inferiora Fgg

Data pada gambar 3-16 menunjukan bahwa tebal terendah dari Dextrum Inferiora FK terdapat pada S9 yakni $0,2 \mathrm{~cm}$ dan tebal tertingginya terdapat pada $\mathrm{S} 1$ dan $\mathrm{S} 2$ yakni $0,5 \mathrm{~cm}$ dengan rata-ratanya yakni $3,5 \mathrm{~cm}$. Sedangkan tebal terendah dari FE terdapat pada S7 dan S9 yakni $0.3 \mathrm{~cm}$ dan tebal tertingginya terdapat pada $S 1$ yakni $0,6 \mathrm{~cm}$ dengan rata-ratanya yakni 4,5 $\mathrm{cm}$.

Data lebar Faciem Superius antara Fgg sampel FE dan Fgg sampel FK di tampilkan pada gambar 3-17

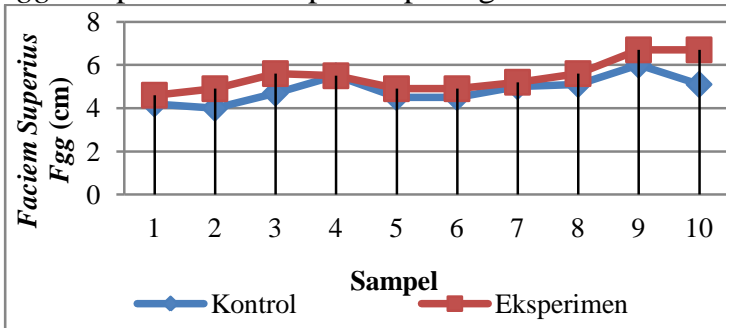

Gambar 3-17 Grafik Data Hasil Lebar Faciem Superius Fgg

Data pada gambar 3-17 menunjukan bahwa lebar terendah dari Faciem Superius FK terdapat pada S2 yakni $4 \mathrm{~cm}$ dan lebar tertingginya terdapat pada $\mathrm{S} 9$ yakni $6 \mathrm{~cm}$ dengan rata-ratanya yakni 48,6 $\mathrm{cm}$. Sedangkan lebar terendah dari FE terdapat pada S1 yakni $4,6 \mathrm{~cm}$ dan lebar tertingginya terdapat pada $\mathrm{S} 9$ dan S10 yakni $6,7 \mathrm{~cm}$ dengan rata-ratanya yakni 54,6 $\mathrm{cm}$.

Data lebar Faciem Medio antara Fgg sampel FE dan Fgg sampel FK di tampilkan pada gambar 3-18

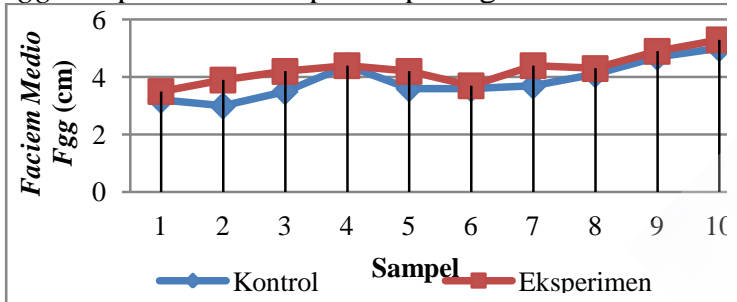

Gambar 3-18 Grafik Data Hasil Faciem Medio Fgg

Data pada gambar 3-18 menunjukan bahwa lebar terendah dari Faciem Medio FK terdapat pada S2 yakni $3 \mathrm{~cm}$ dan lebar tertingginya terdapat pada $\mathrm{S} 10$ yakni $5 \mathrm{~cm}$ dengan rata-ratanya yakni $3,88 \mathrm{~cm}$. Sedangkan lebar terendah dari FE terdapat pada S1 yakni $3,5 \mathrm{~cm}$ dan lebar tertingginya terdapat pada $\mathrm{S} 10$ yakni 5,3 cm dengan rata-ratanya yakni $4,28 \mathrm{~cm}$.

Data lebar Faciem Inferiora antara Fgg sampel FE dan Fgg sampel FK di tampilkan pada gambar 3-19

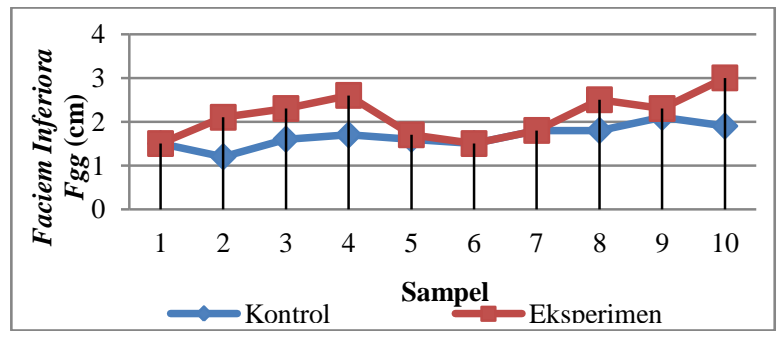

Gambar 3-19 Grafik Data Hasil Faciem Inferiora Fgg

Data pada gambar 3-19 menunjukan bahwa lebar terendah dari Faciem Inferiora FK terdapat pada S2 yakni $1,2 \mathrm{~cm}$ dan lebar tertingginya terdapat pada $\mathrm{S} 9$ yakni 2,1 cm dengan rata-ratanya yakni $1,67 \mathrm{~cm}$. Sedangkan lebar terendah dari FE terdapat pada S1 dan $\mathrm{S} 6$ yakni $1,5 \mathrm{~cm}$ dan lebar tertingginya terdapat pada $\mathrm{S} 4$ yakni $2,6 \mathrm{~cm} 2,13 \mathrm{~cm}$.

Data lebar Tergo Superius antara Fgg sampel FE dan Fgg sampel FK di tampilkan pada gambar 3-20

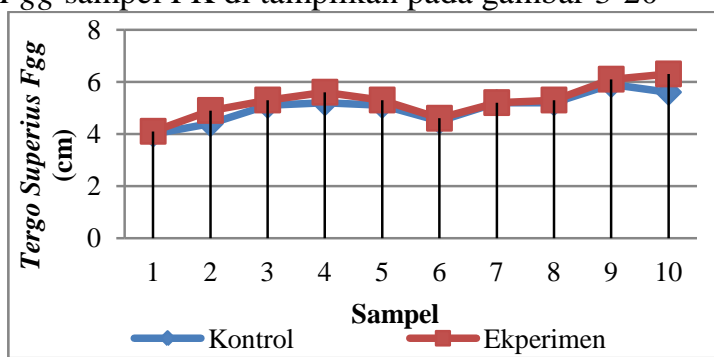

Gambar 3-20 Grafik Data Hasil Lebar Tergo Superius Fgg

Data pada gambar 3-20 menunjukan bahwa lebar terendah dari Tergo Superius FK terdapat pada S1 yakni $4 \mathrm{~cm}$ dan lebar tertingginya terdapat pada $\mathrm{S} 9$ yakni $5,9 \mathrm{~cm}$ dengan rata-ratanya yakni $50,2 \mathrm{~cm}$. Sedangkan lebar terendah dari FE terdapat pada S1 yakni $4,1 \mathrm{~cm}$ dan lebar tertingginya terdapat pada S10 yakni $6,3 \mathrm{~cm}$ dengan rata-ratanya yakni $52,7 \mathrm{~cm}$.

Data lebar Tergo Medio antara Fgg sampel FE dan Fgg sampel FK di tampilkan pada gambar 3-21

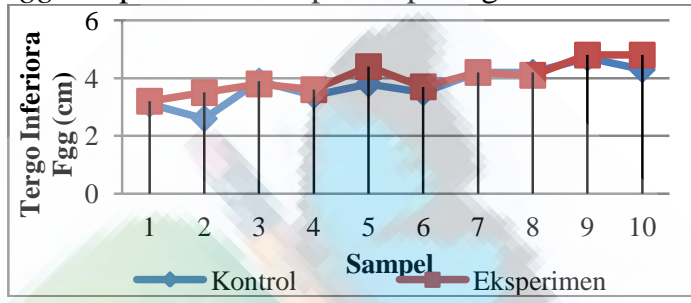

Gambar 3-21 Grafik Data Hasil Lebar Tergo Medio Fgg

Data pada gambar 3-21 menunjukan bahwa lebar terendah dari Tergo Medio FK terdapat pada S2 yakni $2,6 \mathrm{~cm}$ dan lebar tertingginya terdapat pada $\mathrm{S} 9$ yakni 4,7 cm dengan rata-ratanya yakni $37,7 \mathrm{~cm}$. Sedangkan lebar terendah dari FE terdapat pada $\mathrm{S} 1$ yakni $3,2 \mathrm{~cm}$ dan lebar tertingginya terdapat pada $\mathrm{S} 9$ dan S10 yakni 4,8 cm dengan rata-ratanya yakni 40,4 cm.

Data lebar Tergo Inferiora antara Fgg sampel FE dan Fgg sampel FK di tampilkan pada gambar 3-22 


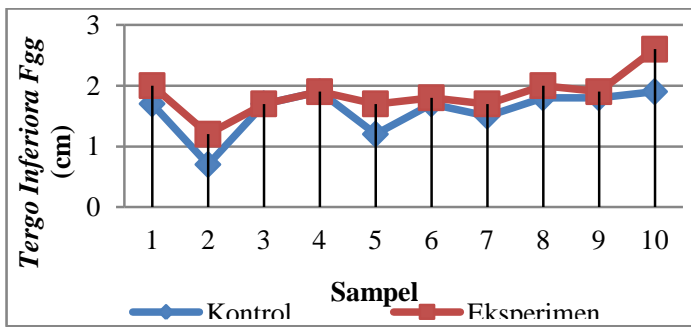

Gambar 3-22 Grafik Data Hasil Lebar Tergo Inferiora Fgg

Data pada gambar 3-22 menunjukan bahwa lebar terendah dari Tergo Inferiora FK terdapat pada S2 yakni $0,7 \mathrm{~cm}$ dan lebar tertingginya terdapat pada $\mathrm{S} 4$ dan S10 yakni $1,9 \mathrm{~cm}$ dengan rata-ratanya yakni 15,9 $\mathrm{cm}$. Sedangkan lebar terendah dari FE terdapat pada $\mathrm{S} 2$ yakni $1,2 \mathrm{~cm}$ dan lebar tertingginya terdapat pada $\mathrm{S} 10$ yakni $2,6 \mathrm{~cm}$ dengan rata-ratanya yakni $18,5 \mathrm{~cm}$.

Data lebar Sinistram Superius Fgg antara Fgg sampel FE dan Fgg sampel FK di tampilkan pada gambar 3-23

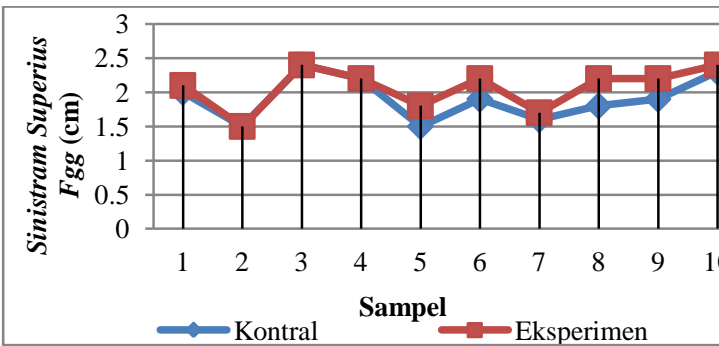

\section{Gambar 3-23 Grafik Data Hasil Sinistram Superius Fgg}

Data pada gambar 3-23 menunjukan bahwa lebar terendah dari Sinistram Superius FK terdapat pada S2 dan S5 yakni $1,5 \mathrm{~cm}$ dan lebar tertingginya terdapat pada S3 yakni 2,4 cm dengan rata-ratanya yakni 19,1 $\mathrm{cm}$. Sedangkan lebar terendah dari FE terdapat pada $\mathrm{S} 2$ yakni $1,5 \mathrm{~cm}$ dan lebar tertingginya terdapat pada $\mathrm{S} 3$ dan S10 yakni $2,4 \mathrm{~cm}$ dengan rata-ratanya yakni $20,7 \mathrm{~cm}$

Data lebar Sinistram Medio antara Fgg sampel FE dan Fgg sampel FK di tampilkan pada gambar 3-24

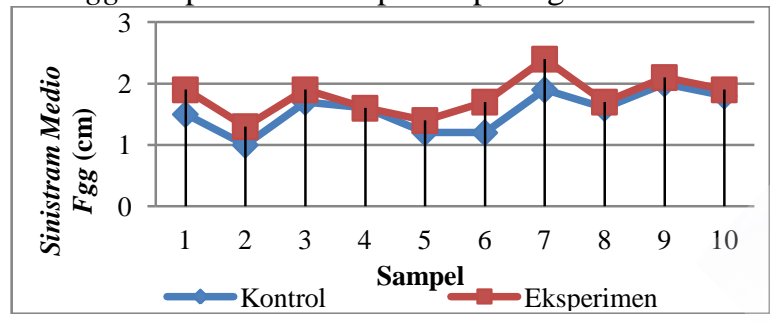

Gambar 3-24 Grafik Data Hasil Sinistram Medio Fgg

Data pada gambar 3-24 menunjukan bahwa lebar terendah dari Sinistram Medio FK terdapat pada S2 yakni $1 \mathrm{~cm}$ dan lebar tertingginya terdapat pada $\mathrm{S} 9$ yakni $2 \mathrm{~cm}$ dengan rata-ratanya yakni $15,5 \mathrm{~cm}$. Sedangkan lebar terendah dari FE terdapat pada S2 yakni $1,3 \mathrm{~cm}$ dan lebar tertingginya terdapat pada $\mathrm{S} 7$ yakni 2,4 cm dengan rata-ratanya yakni $17,9 \mathrm{~cm}$.

Data lebar Sinistram Inferiora antara Fgg sampel FE dan Fgg sampel FK di tampilkan pada gambar 3-25

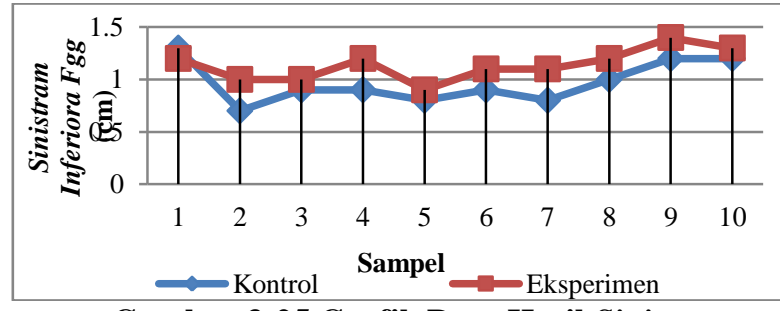

Gambar 3-25 Grafik Data Hasil Sinistram Inferiora Fgg

Data pada gambar 3-25 menunjukan bahwa lebar terendah dari Sinistram Inferiora FK terdapat pada S2 yakni $0,7 \mathrm{~cm}$ dan lebar tertingginya terdapat pada $\mathrm{S} 1$ yakni $1,3 \mathrm{~cm}$ dengan rata-ratanya yakni $9,7 \mathrm{~cm}$. Sedangkan lebar terendah dari FE terdapat pada S2 dan S3 yakni $1 \mathrm{~cm}$ dan lebar tertingginya terdapat pada $\mathrm{S} 9$ yakni $1,4 \mathrm{~cm}$ dengan rata-ratanya yakni $11,5 \mathrm{~cm}$.

Data lebar Dextrum Superius antara Fgg sampel FE dan Fgg sampel FK di tampilkan pada gambar 3-26

Data pada gambar 3-26 menunjukan bahwa lebar terendah dari Dextrum Superius FK terdapat pada S9 yakni $0,9 \mathrm{~cm}$ dan lebar tertingginya terdapat pada $\mathrm{S} 7$ yakni 2,1 cm dengan rata-ratanya yakni $15,7 \mathrm{~cm}$. Sedangkan lebar terendah dari FE terdapat pada S2 dan $\mathrm{S} 3$ yakni $1 \mathrm{~cm}$ dan lebar tertingginya terdapat pada $\mathrm{S} 9$ yakni $1,4 \mathrm{~cm}$ dengan rata-ratanya yakni $18 \mathrm{~cm}$.

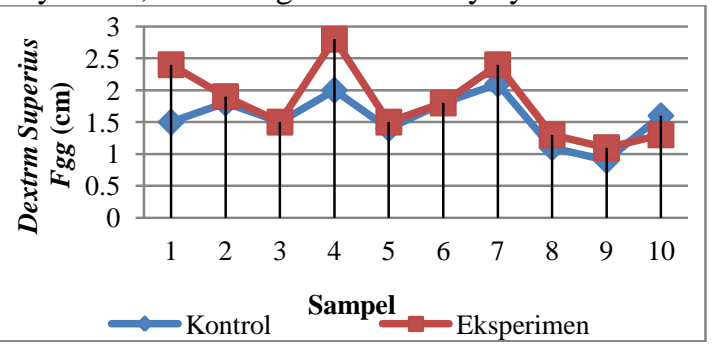

Gambar 3-26 Grafik Data Hasil Dextrum Superius Fgg

Data lebar Dextrum Medio antara Fgg sampel FE dan Fgg sampel FK di tampilkan pada gambar 3-27

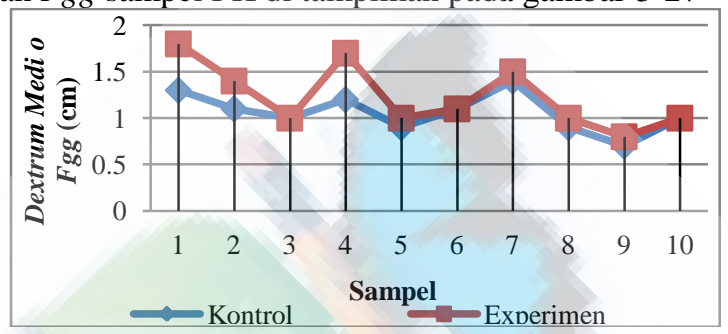

Gambar 3-27 Grafik Data Hasil Dextrum Medio Fgg

Data pada gambar 3-27 menunjukan bahwa lebar terendah dari Dextrum Medio FK terdapat pada S9 yakni $0,7 \mathrm{~cm}$ dan lebar tertingginya terdapat pada S7 yakni $1,4 \mathrm{~cm}$ dengan rata-ratanya yakni $10,6 \mathrm{~cm}$. Sedangkan lebar terendah dari FE terdapat pada S9 yakni $0,8 \mathrm{~cm}$ dan lebar tertingginya terdapat pada $\mathrm{S} 4$ yakni $1,7 \mathrm{~cm} 12,3 \mathrm{~cm}$.

Data lebar Dextrum Inferiora antara Fgg sampel FE dan Fgg sampel FK di tampilkan pada gambar 3-28 


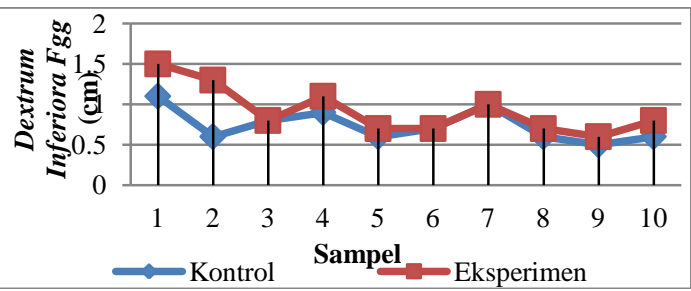

Gambar 3-28 Grafik Data Hasil Dextrum Inferiora Fgg

Data pada gambar 3-28 menunjukan bahwa lebar terendah dari Dextrum Inferiora FK terdapat pada S9 yakni $0,5 \mathrm{~cm}$ dan lebar tertingginya terdapat pada $\mathrm{S} 1$ yakni $1,1 \mathrm{~cm}$ dengan rata-ratanya yakni $7,4 \mathrm{~cm}$. Sedangkan lebar terendah dari FE terdapat pada S9 yakni $0,6 \mathrm{~cm}$ dan lebar tertingginya terdapat pada $\mathrm{S} 1$ yakni $1,5 \mathrm{~cm}$ dengan rata-ratanya yakni $9,2 \mathrm{~cm}$.

Tingkat perubahan yang terjadi pada $\mathrm{FE}$ berdasarkan waktu yang telah ditentukan mulai dari 2 jam sampai dengan 20 jam dengan konsentrasi campuran sebesar $22,5 \%$ yaitu terjadi perubahan warna dan penebalan, pengerutan hingga iritasi ringan yang menyebabkan luka pada bagian kulitnya. Selain itu terdapat lendir atau cairan berwarna yang keluar dari bagian bawah kulitnya.

Data selisih dan persentase massa antara Fgg sampel FE dan Fgg sampel FK di tampilkan pada gambar 3-29

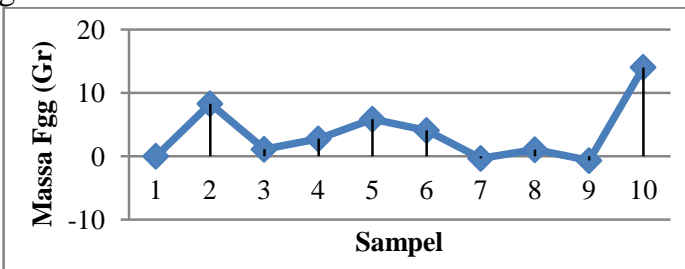

Gambar 3-29 Grafik Data Hasil Selisih Massa Fgg

Data pada gambar 3-29 menunjukan bahwa perbandingan selisih dan persentase massa antara FE dan FK pada jam ke 2 (S1) tidak mengalami perubahan. Perubahan terjadi dengan ditandai kenaikan secara signifikan pada jam ke 4 (S2) sebesar 8,29 gr $(22,41 \%)$ dan mengalami penurunan pada jam ke 6 (S3) sebesar 1,1 gr (2,35\%) setelah itu kembali mengalami kenaikan pada jam ke 8 (S4) sampai dengan jam ke 10 (S5) sebesar 2,75 gr $(5,91 \%)$ hingga 5,85 gr $(12,17 \%)$. Kemudian mengalami penurunan pada jam ke 12 (S6) sampai dengan jam ke 18 (S9) sebesar 4,07 gr $(9,82 \%)$ hingga $-0,68$ gr $(-1,41 \%)$ dan mengalami kenaikan kembali pada jam ke 20 (S10) sebesar 14,04 gr $(27,98 \%)$.

Data selisih dan persentase Superius antara Fgg sampel FE dan Fgg sampel FK di tampilkan pada gambar 3-30

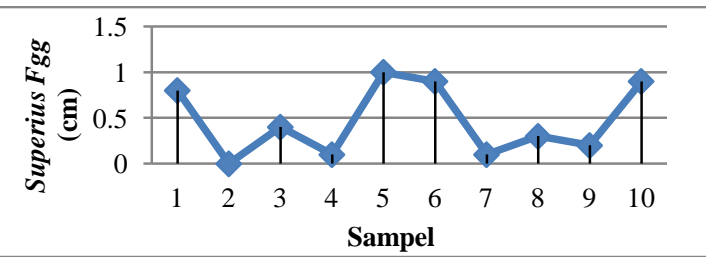

\section{Gambar 3-30 Grafik Data Hasil Selisih Keliling Superius Fgg}

Data pada gambar 3-30 menunjukan bahwa perbandingan selisih dan persentase keliling Superius antara FE dan FK mengalami kenaikan secara signifikan pada jam ke 2 (S1) sebesar $0,8 \mathrm{~cm}(6,95 \%)$ kemudian pada jam ke 4 (S2) tetap dan mengalami kenaikan kembali pada jam ke 6 (S3) sebasar $0,4 \mathrm{~cm}$ $(3,47 \%)$. Penurunan kembali terjadi pada jam ke 8 (S4) sebesar $0,1 \mathrm{~cm}(0.90 \%)$ kemudian mengalami kenaikan pada jam ke 10 (S5) sampai dengan jam ke 12 (S6) sebesar $1 \mathrm{~cm}(10 \%)$ hingga $0.9 \mathrm{~cm}(9,89 \%)$ dan mengalami penurunan pada jam ke 14 (S7) sebesar $0,1 \mathrm{~cm} \quad(0,91 \%)$, setelah itu kembali mengalami kenaikan pada jam ke 16 (S8) $0,3 \mathrm{~cm}$ $(2,94 \%)$. Kemudian mengalami penurunan pada jam ke 18 (S9) sebesar 0,2 cm (1,81\%) dan mengalami kenaikan kembali pada jam ke 20 (S10) sebesar 0,09 $\mathrm{cm}(8,49 \%)$.

Data selisih dan persentase Medio antara Fgg sampel FE dan Fgg sampel FK di tampilkan pada gambar 3-31. Data pada gambar 3-31 menunjukan bahwa perbandingan selisih dan persentase keliling Medio antara FE dan FK mengalami kenaikan secara signifikan pada jam ke 2 (S1) sampai dengan jam ke 4 (S2) sebesar 1,2 cm (15,38\%) hingga 1,4 cm (20\%) kemudian mengalami penurunan pada jam ke 6 (S3) sebesar $-0,1 \mathrm{~cm}(-1,09 \%)$ dan mengalami kenaikan kembali pada jam ke 8 (S4) sebasar 0,6 cm (8\%). Penurunan kembali terjadi pada jam ke 10 (S5) sebesar $0,1 \mathrm{~cm}(1,14 \%)$ kemudian pada jam ke 12 (S6) sampai dengan jam ke 16 (S8) tetap sebesar $0 \mathrm{~cm}(0 \%)$ kemudian mengalami kenaikan kembali pada jam ke 18 (S9) sampai dengan jam ke 20 (S10) sebesar 0,5 cm $(6,32 \%)$ hingga $1,4 \mathrm{~cm}(15,38 \%)$.

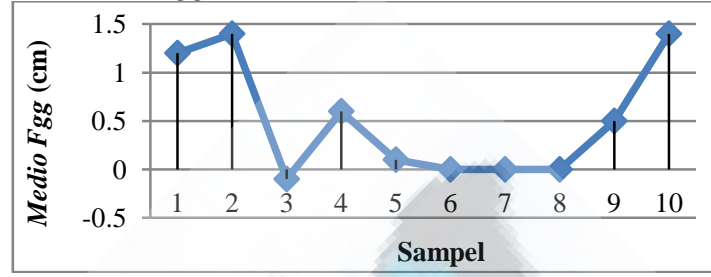

Gambar 3-31 Grafik Data Hasil Selisih Keliling Medio Fgg

Data selisih dan persentase Inferiora antara Fgg sampel FE dan Fgg sampel FK di tampilkan pada gambar 3-32

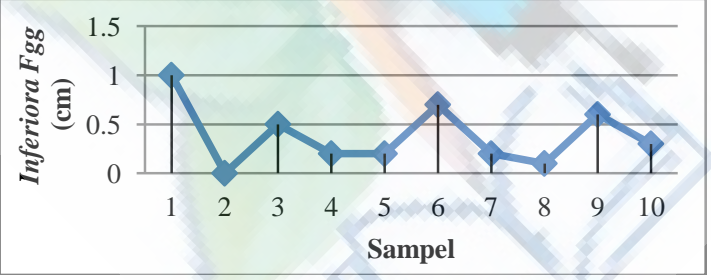

Gambar 3-32 Grafik Data Hasil Selisih Keliling Inferiora Fgg

Data pada gambar 3-32 menunjukan bahwa perbandingan selisih dan persentase keliling Inferiora antara FE dan FK mengalami kenaikan secara signifikan pada jam ke 2 (S1) sebesar $1 \mathrm{~cm}(20 \%)$ 
kemudian pada jam ke 4 (S2) tetap dan mengalami kenaikan kembali pada jam ke 6 (S3) sebasar $0,5 \mathrm{~cm}$ $(11,11 \%)$ kemudian mengalami penurunan pada jam ke 8 (S4) sampai dengan jam ke 10 (S5) sebesar 0,2 $\mathrm{cm}(3,77 \%)$ hingga $0,2 \mathrm{~cm}(4 \%)$. Kenaikan kembali terjadi pada jam ke 12 (S6) sebesar $0,7 \mathrm{~cm}(16,66 \%)$ kemudian mengalami penurunan pada jam ke 14 (S7) sampai dengan jam ke 16 (S8) sebesar 0,2 cm $(3,84 \%)$ hingga $0,1 \mathrm{~cm}(2 \%)$ dan kemudian mengalami kenaikan kembali pada jam ke 18 (S9) sebesar 0,6 cm $(13,33 \%)$ serta mengalami penurunan kembali pada jam ke 20 (S10) sebesar 0,3 cm (6\%).

Data selisih dan persentase Faciem Superius antara Fgg sampel FE dan Fgg sampel FK di tampilkan pada gambar 3-33. Data pada gambar 3-33 menunjukan bahwa perbandingan selisih dan persentase tebal Faciem Superius antara FE dan FK mengalami kenaikan secara signifikan pada jam ke 2 (S1) sampai dengan jam ke 4 (S2) sebesar $0,8 \mathrm{~cm}$ $(1,25 \%)$ hingga $0,9 \mathrm{~cm}(1,11 \%)$ kemudian mengalami penurunan pada jam ke 6 (S3) sebesar $0,7 \mathrm{~cm}(1,14 \%)$ dan mengalami kenaikan kembali pada jam ke 8 (S4) sampai dengan jam 14 (S7) sebasar $0,1 \mathrm{~cm}(0,8 \%)$ hingga $0,8 \mathrm{~cm}(1,25 \%)$. Penurunan kembali terjadi pada jam ke 16 (S8) sebesar 0,5 cm (2\%) kemudian terjadi kenaikan pada jam 18 (S9) sampai dengan jam ke 20 (S10) sebesar $0,7 \mathrm{~cm}(1,42 \%)$ hingga $0,7 \mathrm{~cm}$ $(1,14 \%)$.

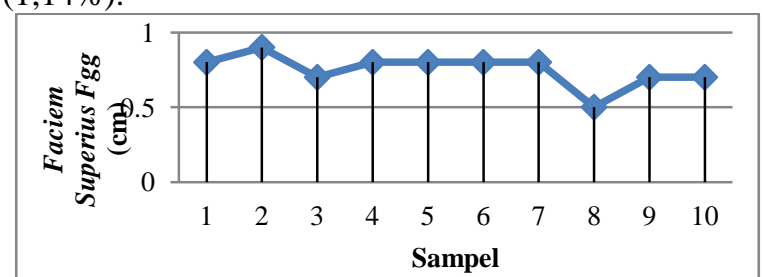

Gambar 3-33 Grafik Data Hasil Selisih Tebal Faciem Superius Fgg

Data selisih dan persentase Faciem Medio antara Fgg sampel FE dan Fgg sampel FK di tampilkan pada gambar 3-34

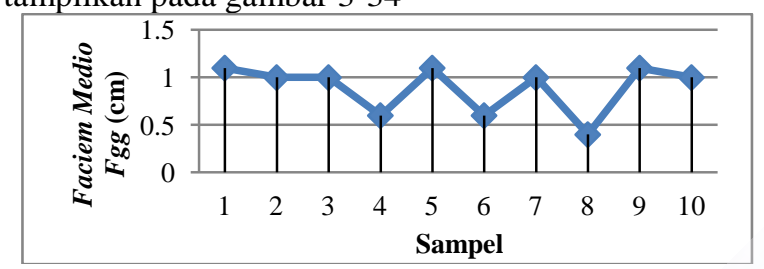

Gambar 3-34 Grafik Data Hasil Selisih Tebal Faciem Medio Fgg

Data pada gambar 3-34 menunjukan bahwa perbandingan selisih dan persentase tebal Faciem Medio antara FE dan FK mengalami kenaikan secara signifikan pada jam ke 2 (S1) sebesar $1,1 \mathrm{~cm}(1,18 \%)$ kemudian mengalami penurunan pada jam ke 4 (S2) sampai dengan jam ke 8 (S4) sebesar $1 \mathrm{~cm}(1,2 \%)$ hingga $0,6 \mathrm{~cm}(1,5 \%)$ dan mengalami kenaikan kembali pada jam ke 10 (S5) sebasar $1,1 \mathrm{~cm}(1 \%)$ kemudian mengalami penurunan pada jam ke 12 (S6) sebesar 0,6 cm (1,83\%). Kenaikan kembali terjadi pada jam ke 14 (S7) sebesar $1 \mathrm{~cm}(1,1 \%)$ kemudian mengalami penurunan pada jam ke 16 (S8) sebesar 0,4 cm $(3, \%)$ dan mengalami kenaikan kembali pada jam ke 18 (S9) sebesar $1,1 \mathrm{~cm}(1,18 \%)$ serta penurunan kembali pada jam ke 20 (S10) sebesar $1 \mathrm{~cm}(1,4 \%)$.

Data selisih dan persentase Faciem Inferiora antara $F g g$ sampel FE dan Fgg sampel FK di tampilkan pada gambar 3-35

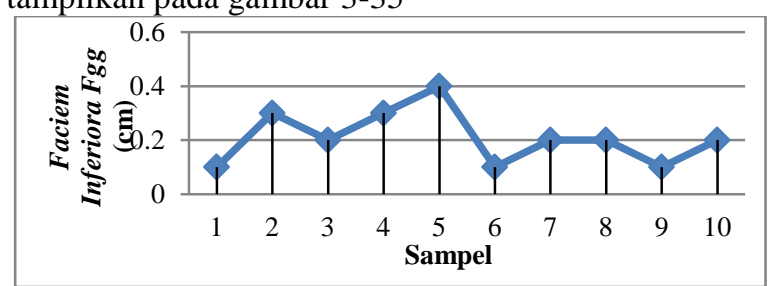

\section{Gambar 3-35 Grafik Data Hasil Selisih Tebal Faciem Inferiora Fgg}

Data pada gambar 3-35 menunjukan bahwa perbandingan selisih dan persentase tebal Faciem Inferiora antara $\mathrm{FE}$ dan $\mathrm{FK}$ mengalami kenaikan secara signifikan pada jam ke 2 (S1) sampai dengan jam ke 4 (S2) sebesar $0,1 \mathrm{~cm}(1 \%)$ hingga $0,3 \mathrm{~cm}$ $(1,33 \%)$ kemudian mengalami penurunan pada jam ke 6 (S3) sebesar 0,2 cm (2\%) dan mengalami kenaikan kembali pada jam ke 8 (S4) sampai dengan jam ke 10 (S5) sebasar $0,3 \mathrm{~cm}$ (1\%) hingga $0,4 \mathrm{~cm} \mathrm{(1 \% )}$ kemudian mengalami penurunan pada jam ke 12 (S6) sebesar $0,1 \mathrm{~cm}(2 \%)$. Kenaikan kembali terjadi pada jam ke 14 (S7) sampai dengan jam ke 16 (S8) sebesar $0,2 \mathrm{~cm} \quad(1,5 \%)$ hingga $0,2 \mathrm{~cm} \quad(1 \%)$ kemudian mengalami penurunan pada jam ke 18 (S9) sebesar 0,1 $\mathrm{cm}(2 \%)$ dan mengalami kenaikan pada jam ke 20 (S10) sebesar 0,2 cm (3\%).

Data selisih dan persentase Tergo Superius antara Fgg sampel FE dan Fgg sampel FK di tampilkan pada gambar 3-36

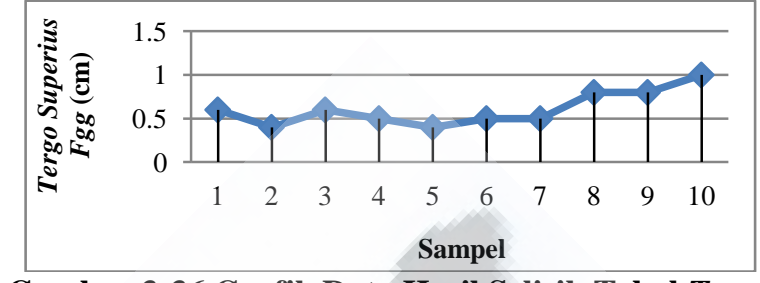

Gambar 3-36 Grafik Data Hasil Selisih Tebal Tergo Superius Fgg

Data pada gambar 3-36 menunjukan bahwa perbandingan selisih dan persentase tebal Tergo Superius antara FE dan FK mengalami kenaikan secara signifikan pada jam ke 2 (S1) sebesar $0,6 \mathrm{~cm}$ $(1,5 \%)$ kemudian mengalami penurunan pada jam ke 4 (S2) sebesar 0,4 cm (1\%) dan mengalami kenaikan kembali pada jam ke 6 (S3) sebesar 0,6 cm $(0,83 \%)$ kemudian mengalami penurunan pada jam ke 8 (S4) sampai dengan jam ke 10 (S5) sebesar $0,5 \mathrm{~cm}(1,2 \%)$ hingga $0,4 \mathrm{~cm}(1,5 \%)$. Kenaikan kembaili terjadi pada jam ke 12 (S6) sampai dengan jam ke 16 (S8) sebesar $0,5 \mathrm{~cm}(0,8 \%)$ hingga $0,8 \mathrm{~cm}(0,75 \%)$ kemudian mengalami penurunan pada jam ke 18 (S9) sebesar 0,8 $\mathrm{cm}(1 \%)$ dan mengalami kenaikan pada jam ke 20 (S10) sebesar $1 \mathrm{~cm}(1,4 \%)$. 
Data selisih dan persentase Tergo Medio antara Fgg sampel FE dan Fgg sampel FK di tampilkan pada gambar 3-37

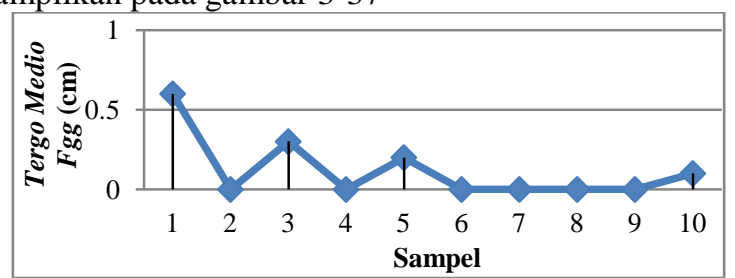

Gambar 3-37 Grafik Data Hasil Selisih Tebal Tergo Medio Fgg

Data pada gambar 3-37 menunjukan bahwa perbandingan selisih dan persentase tebal Tergo Medio antara FE dan FK mengalami kenaikan secara signifikan pada jam ke 2 (S1) sebesar 0,6 cm (120\%) kemudian pada jam ke 4 (S2) tetap dan mengalami kenaikan kembali pada jam ke 6 (S3) sebesar $0,3 \mathrm{~cm}$ $(50 \%)$ kemudian pada jam ke 8 (S4) tetap. Kenaikan kembali terjadi pada jam ke 10 (S5) sebesar $0,2 \mathrm{~cm}$ (40\%) kemudian pada jam ke 12 (S6) sampai dengan jam ke 18 (S9) tetap dan mengalami kenaikan kembali pada jam ke 20 (S10) sebesar 0,1 cm (12,5\%).

Data selisih dan persentase Tergo Inferiora antara Fgg sampel FE dan Fgg sampel FK di tampilkan pada gambar 3-38

Data pada gambar 3-38 menunjukan bahwa perbandingan selisih dan persentase tebal Tergo Inferiora antara FE dan FK mengalami kenaikan secara signifikan pada jam ke 2 (S1) sebesar $0,2 \mathrm{~cm}$ (200\%) kemudian mengalami penurunan pada jam ke 4 (S2) sebesar $0,1 \mathrm{~cm}(100 \%)$ dan mengalami kenaikan kembali pada jam ke 6 (S3) sebesar 0,2 cm $(66,66 \%)$ kemudian mengalami penurunan pada jam ke 8 (S4) sampai dengan jam ke 12 (S6) sebesar 0,1 $\mathrm{cm}(100 \%)$ kemudian pada jam ke 14 (S7) sampai dengan jam ke 16 (S8) tetap. Kenaikan kembaili terjadi pada jam ke 18 (S9) sampai dengan jam ke 20 (S10) sebesar 0,1 cm (100\%).

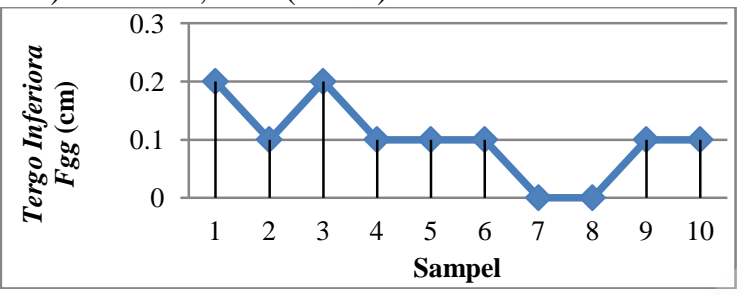

Gambar 3-38 Grafik Data Hasil Selisih Tebal Tergo Inferiora Fgg

Data selisih dan persentase Sinistram

Superius antara Fgg sampel FE dan Fgg sampel FK di tampilkan pada gambar 3-39

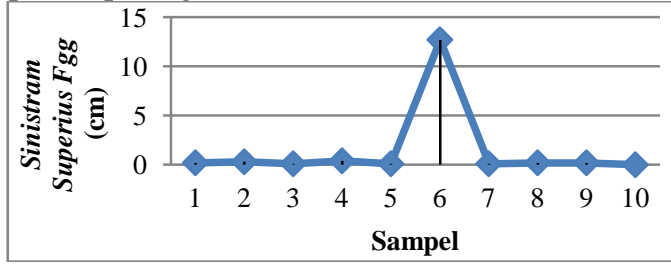

Gambar 3-39 Grafik Data Hasil Selisih Tebal Sinistram Superius Fgg
Data pada gambar 3-39 menunjukan bahwa perbandingan selisih dan persentase tebal Sinistram Superius antara FE dan FK mengalami kenaikan secara signifikan pada jam ke 2 (S1) sampai dengan jam ke 8 (S4) sebesar 0,2 cm (22,22\%) hingga 0,4 cm $(50 \%)$ kemudian mengalami penurunan pada jam ke 10 (S5) sebesar $0,1 \mathrm{~cm}(9,01 \%)$ dan mengalami kenaikan kembali pada jam ke 12 (S6) sebesar 12,7 cm $(976,92 \%)$ kemudian mengalami penurunan pada jam ke 14 (S7) sampai dengan jam ke 18 (S9) sebesar 0,1 $\mathrm{cm}(12,5 \%)$ hingga $0,2 \mathrm{~cm}(13,33 \%)$ dan kemudian pada jam ke 20 (S10) tetap.

Data selisih dan persentase Sinistram Medio antara Fgg sampel FE dan Fgg sampel FK di tampilkan pada gambar 3-40

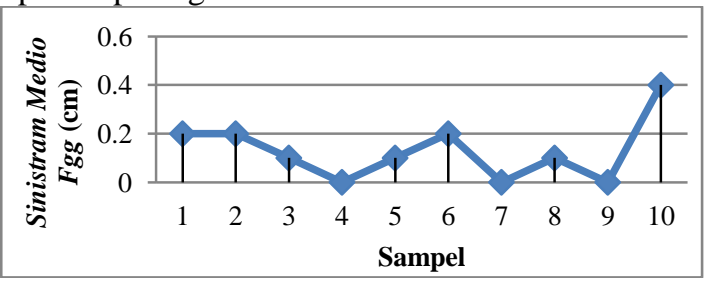

Gambar 3-40 Grafik Data Hasil Selisih Tebal Sinistram Medio Fgg

Data pada gambar 3-40 menunjukan bahwa perbandingan selisih dan persentase tebal Sinistram Medio antara FE dan FK mengalami kenaikan secara signifikan pada jam ke 2 (S1) sampai dengan jam ke 4 (S2) sebesar 0,2 cm (22,22\%) hingga 0,2 cm (14,28\%) kemudian mengalami penurunan pada jam ke 6 (S3) sebesar $0,1 \mathrm{~cm}(10 \%)$ dan kemudian pada jam ke 8 (S4) tetap. Kenaikan kembali terjadi pada jam ke 5 (S10) sampai dengan jam ke 12 (S6) sebesar 0,1 cm $(7,14 \%)$ hingga $0,2 \mathrm{~cm}(15,38 \%)$ kemudian pada jam ke 14 (S7) tetap kemudian mengalami kenaikan kembali pada jam ke 16 (S8) sebesar $0,1 \mathrm{~cm}(6,66 \%)$ dan pada jam ke 18 (S9) tetap serta mengalami kenaikan kembali pada jam ke 20 (S10) sebesar 0,4 cm $(26,66 \%)$.

Data selisih dan persentase Sinistram Inferiora antara Fgg sampel FE dan Fgg sampel FK di tampilkan pada gambar 3-41

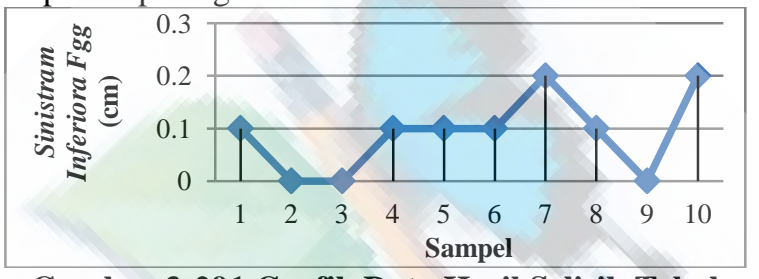

Gambar 3-291 Grafik Data Hasil Selisih Tebal Sinistram Inferiora Fgg

Data pada gambar 3-41 menunjukan bahwa perbandingan selisih dan persentase tebal Sinistram Inferiora antara FE dan FK mengalami kenaikan secara signifikan pada jam ke $2(\mathrm{~S} 1)$ sebesar $0,1 \mathrm{~cm}$ $(14,28 \%)$ kemudian dari jam ke 4 (S2) sampai dengan jam ke 6 (S3) tetap kemudian mengalami kenaikan kembali pada jam ke 8 (S4) sampai dengan jam ke 14 (S7) sebesar 0,1 cm (33,33\%) hingga 0,2 cm $(66,66 \%)$ dan mengalami penurunan kembali pada jam ke 16 
(S8) sebesar 0,1 cm (50\%) pada jam ke 18 (S9) tetap serta mengalami penurunan kembali pada jam ke 20 (S10) sebesar 0,2 cm $(66,66 \%)$.

Data selisih dan persentase Dextrum Superius antara Fgg sampel FE dan Fgg sampel FK di tampilkan pada gambar 3-42

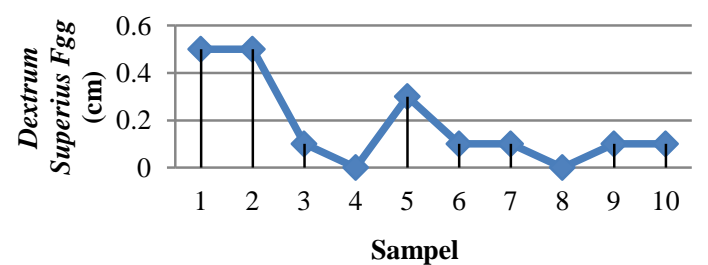

Gambar 3-42 Grafik Data Hasil Selisih Tebal Dextrum Superius Fgg

Data pada gambar 3-42 menunjukan bahwa perbandingan selisih dan persentase tebal Dextrum Superius antara FE dan FK mengalami kenaikan secara signifikan pada jam ke 2 (S1) sampai dengan jam ke 4 (S2) sebesar $0,5 \mathrm{~cm}(38,46 \%)$ hingga $0,5 \mathrm{~cm}$ $(55,55 \%)$ kemudian mengalami penurunan pada jam ke $6(\mathrm{~S} 3)$ sebesar $0,1 \mathrm{~cm}(5,26 \%)$ dan kemudian pada jam ke 8 (S4) tetap. Kenaikan kembali terjadi pada jam ke 10 (S5) sebesar $0.3 \mathrm{~cm}(16,66 \%)$ kemudian penurunan kembali pada jam ke 12 (S6) sampai dengan jam ke 14 (S7) sebesar 0,1 cm (5\%) kemudian pada jam ke 16 (S8) tetap dan mengalami kenaikan pada jam ke 18 (S9) sampai dengan jam ke 20 (S10) sebesar $0,1 \mathrm{~cm}(4,54 \%)$ hingga $0,1 \mathrm{~cm}(5,55 \%)$.

Data selisih dan persentase Dextrum Medio antara Fgg sampel FE dan Fgg sampel FK di tampilkan pada gambar 3-43

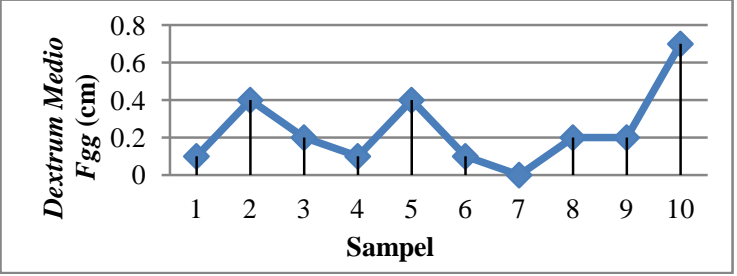

Gambar 3-43 Grafik Data Hasil Selisih Tebal Dextrum Medio Fgg

Data pada gambar 3-43 menunjukan bahwa perbandingan selisih dan persentase tebal Dextrum Medio antara FE dan FK mengalami kenaikan secara signifikan pada jam ke 2 (S1) sampai dengan jam ke 4 (S2) sebesar 0,1 cm (7,14 \%) hingga 0,4 cm (44,44\%) kemudian mengalami penurunan pada jam ke 6 (S3) sampai dengan jam ke 8 (S4) sebesar 0,2 cm (14,28\%) hingga $0,1 \mathrm{~cm}(7,14 \%)$ dan mengalami kenaikan kembali pada jam ke 10 (S5) sebesar 0,4 cm (25\%). Penurunan kembali terjadi pada jam 12 (S6) sebesar 5 $\mathrm{cm}(5,55 \%)$ pada jam ke 14 (S7) tetap dan mengalami kenaikan kembali pada jam ke 16 (S8) sampai dengan jam ke 20 (S10) sebesar 0,2 cm (14,28\%) hingga 0,7 $\mathrm{cm}(50 \%)$.

Data selisih dan persentase Dextrum Inferiora antara Fgg sampel FE dan Fgg sampel FK di tampilkan pada gambar 3-44

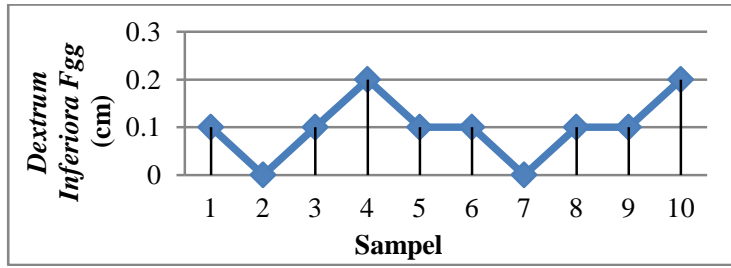

Gambar 3-44 Grafik Data Hasil Selisih Tebal Dextrum Inferiora Fgg

Data pada gambar 3-44 menunjukan bahwa perbandingan selisih dan persentase tebal Dextrum Inferiora antara FE dan FK mengalami kenaikan secara signifikan pada jam ke 2 (S1) sebesar $0,1 \mathrm{~cm}$ (20\%) kemudian pada jam ke 4 (S2) tetap kemudian mengalami kenaikan kembali pada jam ke 6 (S3) sampai dengan jam ke 8 (S4) sebesar 0,1 cm (25\%) hingga $0,2 \mathrm{~cm}(66,66 \%)$ dan mengalami penurunan kembali pada jam ke 10 (S5) sampai dengan jam ke 12 (S6) sebesar 0,1 cm (25\%) hingga 0,1 cm $(33,33 \%)$ pada jam ke 14 (S7) tetap serta mengalami kenaikan kembali pada jam ke 16 (8) sampai dengan jam ke 20 (S10) sebesar $0,1 \mathrm{~cm} \quad(3,33 \%)$ hingga $0,2 \mathrm{~cm}$ $(66,66 \%)$.

Data selisih dan persentase Faciem Superius antara Fgg sampel FE dan Fgg sampel FK di tampilkan pada gambar 3-45

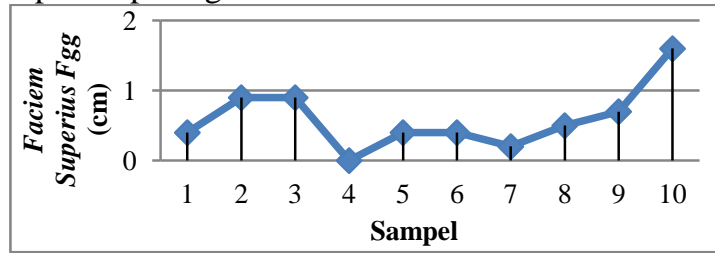

Gambar 3-45 Grafik Data Hasil Selisih Lebar Faciem Superius Fgg

Data pada gambar 3-45 menunjukan bahwa perbandingan selisih dan persentase tebal Faciem Superius antara FE dan FK mengalami kenaikan secara signifikan pada jam ke 2 (S1) sampai dengan jam ke 6 (S3) sebesar 0,4 cm (9,52\%) hingga 0,9 cm $(19,14 \%)$ kemudian mengalami penurunan pada jam ke 8 (S4) tetap kemudian mengalami kenaikan kembali pada jam ke 10 (S5) sampai dengan jam ke 12 (S6) sebesar 0,4 cm (88,88\%) hingga $0,4 \mathrm{~cm}(88,88 \%)$ dan mengalami penurunan kembali pada jam ke 14 (S7) sebesar $0,2 \mathrm{~cm}(4 \%)$ serta mengalami kenaikan kembali pada jam ke 16 (8) sampai dengan jam ke 20 (S10) sebesar $0,5 \mathrm{~cm}(9,80 \%)$ hingga $1,6 \mathrm{~cm}$ $(36.37 \%)$.

Data selisih dan persentase Faciem Medio antara Fgg sampel FE dan Fgg sampel FK di tampilkan pada gambar 3-46

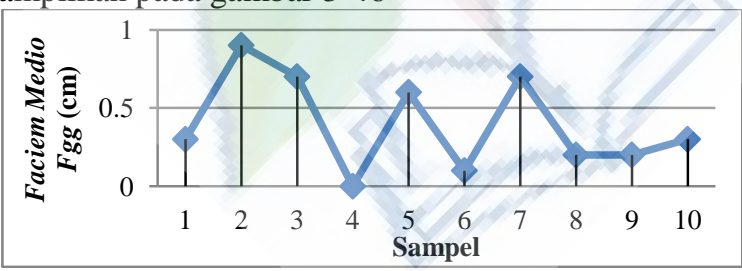

Gambar 3-46 Grafik Data Hasil Selisih Lebar Faciem Medio Fgg 
Data pada gambar 3-45 menunjukan bahwa perbandingan selisih dan persentase tebal Faciem Medio antara FE dan FK mengalami kenaikan secara signifikan pada jam ke 2 (S1) sampai dengan jam ke 4 (S2) sebesar 0,3 cm (9,37\%) hingga 0,9 $\mathrm{cm}(30 \%)$ kemudian mengalami penurunan pada jam ke 6 (S3) sebesar 0,7 cm (20\%) kemudian pada jam ke 8 (S4) tetap kemudian mengalami kenaikan kembali pada jam ke 10 (S5) sebesar $0.6 \mathrm{~cm}(16,66 \%)$ dan mengalami penurunan kembali pada jam ke 12 (S6) sebesar 0,1 cm $(2,77 \%)$. Kenaikan kembali terjadi pada jam ke 14 (S7) sebesar 0,7 cm $(18,91 \%)$ kemudian mengalami penurunan pada jam ke 16 (S8) sampai dengan jam ke 18 (S9) sebesar $0,2 \mathrm{~cm}(4,87 \%)$ hingga $0,2 \mathrm{~cm}(4,25 \%)$ dan mengalami kenaikan kembali pada jam ke 20 (10) sebesar $0,3 \mathrm{~cm}(6 \%)$,

Data selisih dan persentase Faciem Inferiora antara Fgg sampel FE dan Fgg sampel FK di tampilkan pada gambar 3-47

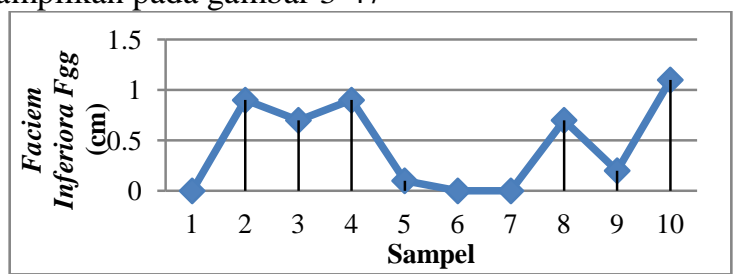

Gambar 3-7 Grafik Data Hasil Selisih Lebar Faciem Inferiora Fgg

Data pada gambar 3-47 menunjukan bahwa perbandingan selisih dan persentase tebal Faciem Inferiora antara FE dan FK mengalami kenaikan secara signifikan pada jam ke 2 (S1) tetap kemudan mengalami kenaikan pada jam ke 4 (S2) sebesar 0,9 $\mathrm{cm}(75 \%)$ kemudian mengalami penurunan pada jam ke 6 (S3) sebesar $0,7 \mathrm{~cm}(43 \%)$ kemudian mengalami kenaikan kembai pada jam ke 8 (S4) sebesar 0,9 gr $(52,94 \%)$ dan kemudian mengalami penurunan kembali pada jam ke 10 (S5) sebesar $0.1 \mathrm{~cm}(6,25 \%)$ serta pada jam ke 12 (6) sampai dengan jam 16 (8) tetap. Kenaikan kembali terjadi pada jam ke 16 (S8) sebesar $0,7 \mathrm{~cm} \quad(3,88 \%)$ kemudian mengalami penurunan pada jam ke 18 (S9) sebesar $0,2 \mathrm{~cm}$ $(9,52 \%)$ serta mengalami kenaikan kembali pada jam ke 20 (S10) sebesar 1,1 cm (57,89\%).

Data selisih dan persentase Tergo Superius antara Fgg sampel FE dan Fgg sampel FK di tampilkan pada gambar 3-48

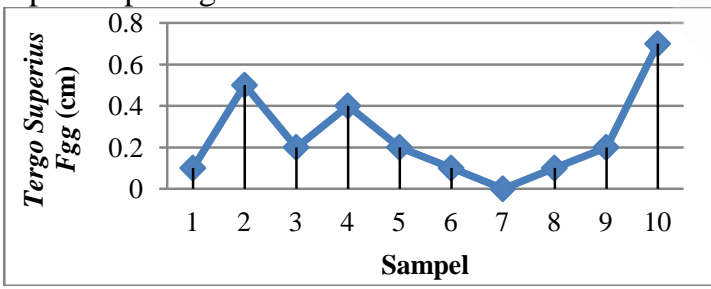

Gambar 3-48 Grafik Data Hasil Selisih Lebar Tergo Superius Fgg

Data pada gambar 3-48 menunjukan bahwa perbandingan selisih dan persentase tebal Tergo Superius antara FE dan FK mengalami kenaikan secara signifikan pada jam ke 2 (S1) sampai dengan jam ke $4(\mathrm{~S} 2)$ sebesar $0,1 \mathrm{~cm}(2,5 \%)$ hingga $0,5 \mathrm{~cm}$ $(11,36 \%)$ kemudian mengalami penurunan pada jam ke 6 (S3) sebesar 0,2 cm (3,92\%) kemudian mengalami kenaikan kembali pada jam ke 8 (S4) sebesar $0,4 \mathrm{~cm}(7,69 \%)$ dan kemudian mengalami penurunan kembali pada jam ke 10 (S5) sampai dengan jam ke 12 (S6) sebesar $0.2 \mathrm{~cm}(3,92 \%)$ hingga $0,1 \mathrm{~cm}(2,22 \%)$ kemudian pada jam ke 14 tetap serta mengalami kenaikan kembali pada jam ke 16 (S8) sampai dengan jam ke 20 (S10) sebesar $0,1 \mathrm{~cm}$ $(1,92 \%)$ hingga $0,7 \mathrm{~cm}(12,5 \%)$.

Data selisih dan persentase Tergo Medio antara Fgg sampel FE dan Fgg sampel FK di tampilkan pada gambar 3-49

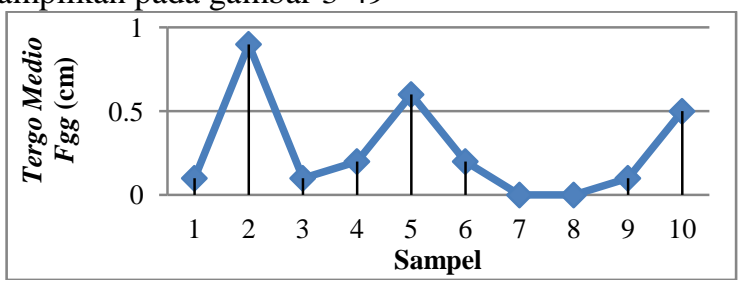

Gambar 3-49 Grafik Data Hasil Selisih Lebar Tergo Medio Fgg

Data pada gambar 3-49 menunjukan bahwa perbandingan selisih dan persentase tebal Tergo Medio antara FE dan FK mengalami kenaikan secara signifikan pada jam ke 2 (S1) sampai dengan jam ke 4 (S2) sebesar $0,1 \mathrm{~cm}(3,22 \%)$ hingga $0,9 \mathrm{~cm}(34,61 \%)$ kemudian mengalami penurunan pada jam ke 6 (S3) sebesar $0,1 \mathrm{~cm} \quad(2,56 \%)$ kemudian mengalami kenaikan kembali pada jam ke 8 (S4) sampai dengan jam ke 10 (S5) sebesar 0,6 cm (15,78\%) dan kemudian mengalami penurunan kembali pada jam ke 12 (S6) sebesar $0,2 \mathrm{~cm}(5,71 \%)$ kemudian pada jam ke 14 (S7) sampai dengan jam ke 16 (S8) tetap serta mengalami kenaikan kembali pada jam ke 18 (S9) sampai dengan jam ke 20 (S10) sebesar $0,1 \mathrm{~cm}$ $(2,12 \%)$ hingga $0,5 \mathrm{~cm}(11,62 \%)$.

Data selisih dan persentase Tergo Inferiora antara Fgg sampel FE dan Fgg sampel FK di tampilkan pada gambar 3-50

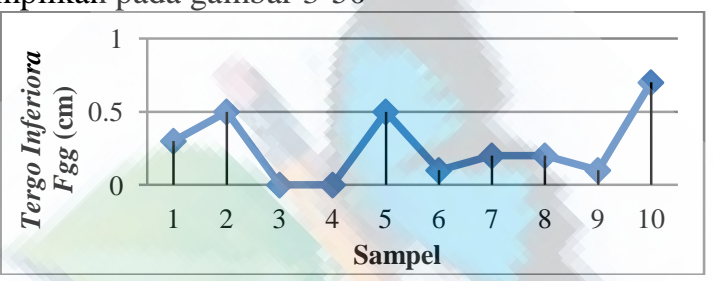

Gambar 3-50 Grafik Data Hasil Selisih Lebar Tergo Inferiora Fgg

Data pada gambar 3-50 menunjukan bahwa perbandingan selisih dan persentase tebal Tergo Inferiora antara $\mathrm{FE}$ dan $\mathrm{FK}$ mengalami kenaikan secara signifikan pada jam ke 2 (S1) sampai dengan jam ke 4 (S2) sebesar 0,1 cm (17,64\%) hingga 0,5 cm $(71,42 \%)$ kemudian pada jam ke 6 (S3) sampai dengan jam ke 8 (S4) tetap kemudian mengalami kenaikan kembali pada jam ke 10 (S5) sebesar 0,5 cm (41,66\%) dan kemudian mengalami penurunan kembali pada jam ke 12 (S6) sebesar 0,2 cm (13,33\%). Kenaikan 
kembali terjadi pada jam ke 14 (S7) sampai dengan jam ke 16 (S8) sebesar 0,2 cm (13,33\%) hingga 0,2 cm $(11,11 \%)$ kemudian mengalami penurunan pada jam ke 18 (S9) sebesar 0,1 cm (5,55\%) dan kenaikan kembali pada jam ke 20 (S10) sebesar $0,7 \mathrm{~cm}$ $(36,84 \%)$.

Data selisih dan persentase Sinistram Superius antara Fgg sampel FE dan Fgg sampel FK di tampilkan pada gambar 3-51

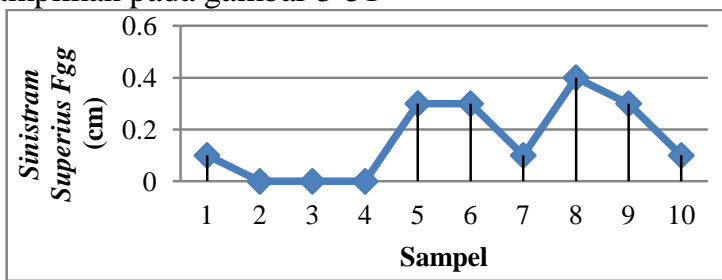

Gambar 3-51 Grafik Data Hasil Selisih Lebar Sinistram Superius Fgg

Data pada gambar 3-51 menunjukan bahwa perbandingan selisih dan persentase tebal Sinistram Superius antara FE dan FK mengalami kenaikan secara signifikan pada jam ke 2 (S1) sebesar $0,1 \mathrm{~cm}$ (5\%) kemudian pada jam ke 4 (S2) sampai dengan jam ke 8 (S4) tetap kemudian mengalami kenaikan kembali pada jam ke 10 (S5) sampai dengan jam ke 12 (S6) sebesar $0,3 \mathrm{~cm}(20 \%)$ hingga $0,3 \mathrm{~cm}(15,78 \%)$ dan kemudian mengalami penurunan kembali pada jam ke 14 (S7) sebesar 0,1 cm (6,25\%). Kenaikan kembali terjadi pada jam ke 16 (S8) sebesar $0.4 \mathrm{~cm} \mathrm{(22,22 \% )}$ kemudian mengalami penurunan pada jam ke 18 (S9) sampai dengan jam ke 20 (S10) sebesar $0,3 \mathrm{~cm}$ $(15,78 \%)$ hingga $0,1 \mathrm{~cm}(4,34 \%)$.

Data selisih dan persentase Sinistram Medio antara Fgg sampel FE dan Fgg sampel FK di tampilkan pada gambar 3-52. Data pada gambar 3-52 menunjukan bahwa perbandingan selisih dan persentase tebal Sinistram Medio antara FE dan FK mengalami kenaikan secara signifikan pada jam ke 2 (S1) sebesar 0,4 cm $(26,66 \%)$ kemudian mengalami penurunan pada jam ke 4 (S2) sampai dengan jam ke 6 (S3) sebesar 0,3 cm (30\%) hingga 0,2 cm (11,76\%) kemudian pada jam ke 8 (S4) tetap kemudian mengalami kenaikan kembali pada jam ke 10 (S5) sampai dengan jam ke 14 (S7) sebesar $0,2 \mathrm{~cm}$ $(16,66 \%)$ hingga $0,5 \mathrm{~cm}(26,31 \%)$ dan kemudian mengalami penurunan kembali pada jam ke 16 (S8) sampai dengan jam ke 20 (S10) sebesar $0,1 \mathrm{~cm}$ $(6,25 \%)$ hingga $0,1 \mathrm{~cm}(5,55 \%)$.

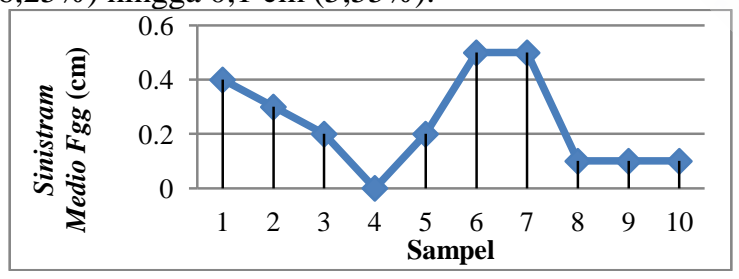

Gambar 3-52 Grafik Data Hasil Selisih Lebar Sinistram Medio Fgg

Data selisih dan persentase Sinistram Inferiora antara Fgg sampel FE dan Fgg sampel FK di tampilkan pada gambar 3-53

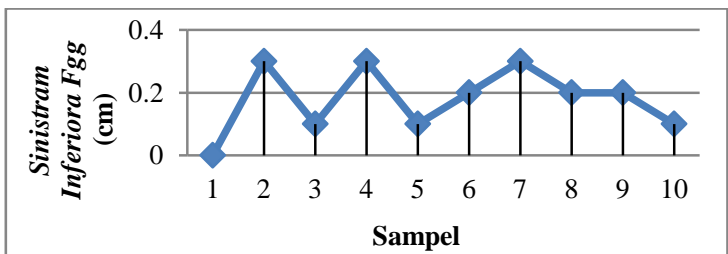

Gambar 3-53 Grafik Data Hasil Selisih Lebar Sinistram Inferiora Fgg

Data pada gambar 3-52 menunjukan bahwa perbandingan selisih dan persentase tebal Sinistram Inferiora antara FE dan FK pada jam ke 2 (S1) tidak mengalami perubahan. Perubahan terjadi dengan ditandai kenaikan secara signifikan pada jam ke 4 (S2) sebesar $0,3 \mathrm{~cm} \quad(42,84 \%)$ kemudian mengalami penurunan pada jam ke 6 (S3) sebesara $0,1 \mathrm{~cm}$ $(11,11 \%)$ kemudian mengalami kenaikan kembai pada jam ke 8 (S4) sebesar 0,3 cm (33,33\%) dan kemudian mengalami penurunan kembali pada jam ke 10 (S5) sebesar $0,1 \mathrm{~cm}(12,5 \%)$. Kenaikan kembali terjadi pada jam ke 12 (S6) sampai dengan jam ke 14 (S7) sebesar $0,2 \mathrm{~cm}(22,22 \%)$ hingga $0,3 \mathrm{~cm}(37,5 \%)$ kemudian mengalami penurunan pada jam ke 16 (S8) sampai dengan jam ke 20 (S10) sebesar 0,2 cm (20\%) hingga $0,1 \mathrm{~cm}(8,33 \%)$.

Data selisih dan persentase Dextrum Superius antara Fgg sampel FE dan Fgg sampel FK di tampilkan pada gambar 3-54

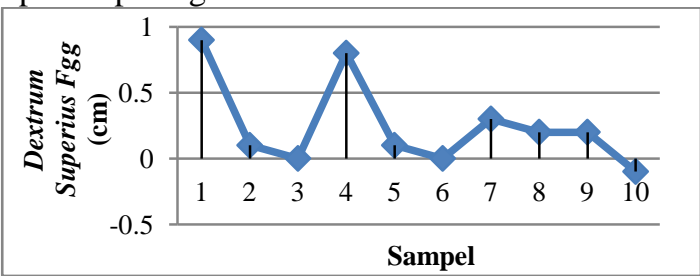

Gambar 3-54 Grafik Data Hasil Selisih Lebar Dextrum Superius Fgg

Data pada gambar 3-54 menunjukan bahwa perbandingan selisih dan persentase tebal Dextrum Superius antara FE dan FK mengalami kenaikan secara signifikan pada jam ke 2 (S1) sebesar 0,9 cm $(60 \%)$ kemudian mengalami penurunan pada jam ke 4 (S2) sebesar 0,1 cm $(5,55 \%)$ pada jam ke 6 (S\#) tetap kemudian mengalami kenaikan kembali pada jam ke 8 (S4) sebesar $0,8 \mathrm{~cm}(40 \%)$ dan kemudian mengalami penurunan kembali pada jam ke 10 (S5) sebesar 0,1 cm $(7,14 \%)$ kemudian pada jam ke 12 (S6) tetap. Kenaikan kembali terjadi pada jam ke 14 (S7) sebesar $0,3 \mathrm{~cm}(14,28 \%)$ kemudian mengalami penurunan pada jam ke 16 (S8) sampai dengan jam ke 20 (S10) sebesar $0,2 \mathrm{~cm}(18,18 \%)$ hingga $-0,1 \mathrm{~cm}(-7,14 \%)$.

Data selisih dan persentase Dextrum Medio antara Fgg sampel FE dan Fgg sampel FK di tampilkan pada gambar 3-56

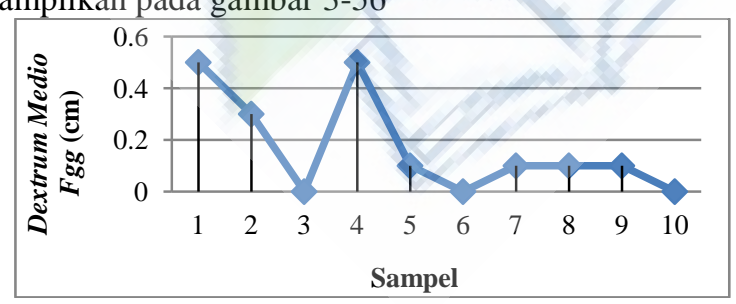




\section{Gambar 3-56 Grafik Data Hasil Selisih Lebar Dextrum Medio Fgg}

Data pada gambar 3-56 menunjukan bahwa perbandingan selisih dan persentase tebal Dextrum Medio antara FE dan FK mengalami kenaikan secara signifikan pada jam ke 2 (S1) sebesar 0,5 cm $(38,46 \%)$ kemudian mengalami penurunan pada jam ke 4 (S2) sebesar 0,3 cm $(27,27 \%)$ kemudian pada jam ke 6 (S3) tetap dan kemudian mengalami kenaikan kembali pada jam ke 8 (S4) sebesar 0,5 cm (41,66\%) serta kemudian mengalami penurunan kembali pada jam ke 10 (S5) sebesar $0,1 \mathrm{~cm}(11,11 \%)$ kemudian pada jam ke !2(S6) tetap. Kenaikan kembali terjadi pada jam ke 14 (S7) sampai dengan jam ke 18 (S9) sebesar $0,1 \mathrm{~cm}$ $(7,14 \%)$ hingga $0,1 \mathrm{~cm}(14,28 \%)$ kemudian pada jam ke 20 (S10) tetap.

Data selisih dan persentase Dextrum Inferiora antara Fgg sampel FE dan Fgg sampel FK di tampilkan pada gambar 3-57

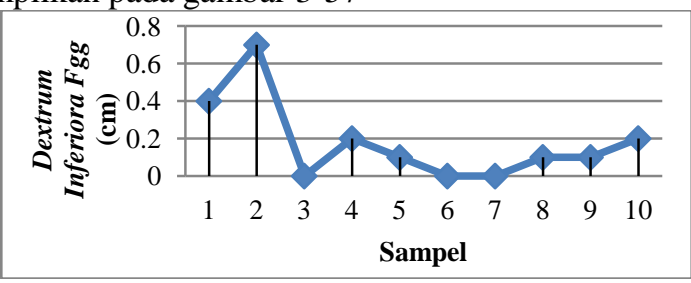

Gambar 3-57 Grafik Data Hasil Selisih Lebar Dextrum Inferiora Fgg

Data pada gambar 3-57 menunjukan bahwa perbandingan selisih dan persentase tebal Dextrum Inferiora antara FE dan FK mengalami kenaikan secara signifikan pada jam ke 2 (S1) sampai dengan jam ke 4 (S2) sebesar 0,4 cm (36,36\%) hingga 0,7 cm $(116,66 \%)$ kemudian pada jam ke 6 (S3) tetap. Kenaikan kembali terjadi pada jam ke 8 (S4) sebesar $0,2 \mathrm{~cm}(22,22 \%)$ kemudian mengalami penurunan pada jam ke 10 (S5) sebesar 0,1 cm (16,66\%) kemudian pada jam ke 12 (S6) sampai jam ke 14 (S7) tetap dan mengalami kenaikan kembali pada jam ke 16 (S8) sampai dengan jam ke 20 (S10) sebesar $0,1 \mathrm{~cm}$ $(16,66 \%)$ hingga $0,2 \mathrm{~cm}(33,33 \%)$.

Hasil perhitungan selisih dan persentase menunjukan bahwa massa, keliling, tebal dan lebar antara sampel eksperimen dan sampel kontrol dari Fgg ini tidak sama atau mengalami perubahan. Hal ini terjadi karena adanya aktivitas dari daun Smilax $S p$ dan gelatin yang menyebabkan inflamasi. Inflamasi merupakan salah satu respon tubuh terhadap zat kimia beracun yang ditandai dengan munculnya sensasi panas, kemerahan, gangguan fungsi tubuh dan edema (15). Edema merupakan akibat dari penumpukan cairan yang terjadi pada bagian pembuluh darah (16).

Edema yang terjadi pada penelitian ini lebih kecil dibandingkan dengan edema dari penelitian yang dilakukan oleh Tualeka pada tahun 2019(17). Hal tersebut disebabkan karena dalam penelitian ini terdapat efek penambahan gelatin yang dicampurkan dengan daun Smilax $S p$, sehingga menjadi suatu campuran yang berfungsi untuk mengurangi kadar edema pada sampel eksperimen.
Edema dalam penelitian ini juga diikuti dengan beberapa gejala lainnya seperti perubahan warna, penebalan dan pengerutan kulit mulai dari S1 sampai dengan S10 serta iritasi ringan yang menyebabkan sobek pada bagian kulit S10. Namun gejala ini tidak sebanding dengan penelitian terdahulu karena campuran yang digunakan dalam penelitian ini memiliki sifat- sifat tertentu seperti dapat memberikan efek dingin pada kulit sehingga sensasi panas yang ditimbulkan akibat dari edemi tersebut menjadi berkurang dan sifat lainnya yaitu tidak menghambat fungsi fisiologis Gallus-gallus domesticus(18).

Berdasarkan penelitian diperoleh pengaruh gelatin pada larutan Smilax $S p$ yakni pengaruhnya mengurangi edema. Edema yang terjadi pada jam ke 2 (S1), jam ke 4 (S2), jam ke 6 (S3), jam ke 8 (S4), jam ke 10 (S5), jam ke 12 (S6), jam ke 14 (S7), jam ke 16 (S8) dan jam ke 18 (S9) lebih kecil dan tidak terjadi iritasi pada kulit serta sedangkan edema tertingginya terdapat pada jam ke 20 (S10) dengan persentase sebesar 8,49 \% dibandingkan dengan edema dari penelitian yang dilakukan oleh Pellaupessy pada tahun 2020 edema tertingginya terdapat pada jam ke 14 (S7) dengan persentase sebesar 114\% (19). Maka diketahui pengaruh dari penambahan gelatin mengalami efek edema baik dari sisi waktu proses terjadinya edema maupun dari besarnya edema dimana penambahan gelatin mengakibatkan memperlambat proses edema dan memperkecil besar edema.

\section{KESIMPULAN}

Berdasarkan hasil penelitian maka dapat disimpulkan bahwa pengaruh dari penambahan gelatin mengalami efek edema baik dari sisi waktu proses terjadinya edema, maupun dari besarnya edema dimana penambahan gelatin mengakibatkan memperlambat proses edema dan memperkecil besar edema. Beberapa sampel menunjukkan bahwa lamanya waktu dapat berpangaruh pada edema, dikarenakan waktu maksimal pencapaian suatu zat bervariasi. Edema pada penelitian ini memiliki persentase massa tertinggi pada jam ke 20 (S10) sebesar 27,98\%, kelilingnya pada jam ke 12 (S6) sebesar 9,89\%, tebalnya pada jam ke 16 (S8) 2\% dan lebarnya pada jam ke 20 (10) 125,79\%

\section{DAFTAR PUSTAKA}

1. Approach to leg edema of unclear etiology. Ely JW, Osheroff,Chambliss L, Ebell MH. 2006, J Am Board Fam Med, pp. 19:148-60.

2. Chronic peripheral oedema: the critical role of the lymphatic system. Mortimer PS \& Levick JR. 2004, Clin Med, pp. 4(5): 448-53.

3. Lymphedema. Rockson, SG. 2001, Am J Med, pp. 110:288-295.

4. Petrucci, R.H. Kimia Dasar Prinsip dan Terapan Modern Jilid 2. . Jakarta : Gramedia, 1985.

5. Perancangan Sistem Pengukuran Konsentrasi Larutan Gula Menggunakan Metode Difraksi. Styarini, L. W. 2012, Jurnal Teknik Pomits., pp. 15. 
6. Texture and microstructure of gelatin/corn starchbased gummy confections. Marfil PH, et al. 2012, Food Biophys, pp. 236-43.

7. The role of salt washing of fish skins in chemical and rheological properties of gelatin extracted. Gimenez, B., Gormez-Guillen, M.C. and Montero, P. 2005, Journal of Food Hydrocolloids, pp. 951-957.

8. Formation and properties of collagen and gelatin films and coatings. Arvanitoyannis, I. S. 2002, In: Gennadios A (Ed.) Protein-based films and coatings. CRC Press, Boca Raton, pp, pp. 275-304.

9. The effect of processing conditions on the properties of gelatin from skate (Raja Kenojei) skins. Cho S-H, Jahncke ML, Chin K-B, Eun J-B. 2006, Food Hydrocoll, pp. 810-816.

10. Extraction and characterization of gelatin from chicken feet by acid and ultrasound assisted extraction. Widyasari, R. and S. Rawdkuen. 2014, Food Appl. Biosci. J., pp. 83-95.

11. Steroidal Saponins from the Rhizomes And Roots of Smilax scobinicaulis. Zhang et al. 2012, Phytochemistry Letters, pp. 49-52.

12. Psikologi Eksperimen. Latipun. 2004, pp. 70-71.

13. IDENTIFIKASI PROSES Edemi EFEK DARI Smilax Sp. Tualeka. 2019, BIOLEARNING JOURNAL.

14. TEKNIK SAMPLING. Nasution. R, SKM. 2003, pp. 1-7.

15. Uji Aktivitas Antiinflamasi Ekstrak Etanol Daun Pisang Ambon (Musa Paradisiaca L.) Terhadap Tikus Putih (Rattus Norvegicus L.) Yang Diinduksi Karagenan . . Sukmawati, et al. 2015, GALENIKA Journal of Pharmacy, pp. 126-132.

16. The Journal of Inflammation. Punchard. N. A, et al. 2004, Journal of Inflammation, pp. 1-4.

17. IDENTIFIKASI PROSES Edemi EFEK DARI Smilax Sp. Tualeka. 2019, BIOLEARNING JOURNAL.

18. R. Voight. Buku Pelajaran Teknologi farmasi. Yogyakarta : Gadjah Mada University Press, 1995.

19. EFEK LAMA WAKTU PENGGUNAAN PADA Femur Gallus gallus domesticus. Pellaupessy. 2020, BIOLEARNING JOURNAL, p. 36. 